\title{
Arquivos de Pessoa(s): um estudo sobre entendimentos e representações dos arquivos manuscritos na Casa Fernando Pessoa
}

Pessoa's Archive: a study about understandings and representations of archival manuscripts in the Casa Fernando Pessoa

\section{TAIGUARA VILLELA ALDABALDE'}

Universidade Fernando Pessoa / Porto, Portugal

RESUMO: Este artigo apresenta os resultados de uma investigação de pós-doutoramento. A pesquisa procura discutir a compreensão dos manuscritos arquivísticos de Fernando Pessoa como um espólio e inferir o quantitativo das representações desses documentos, bem como identificar as práticas através das quais essas representações foram mediadas na Casa Fernando Pessoa. método histórico-documental é adotado, considerando como base empírica os produtos, o espaço do museu e a documentação administrativa de 2006 a 2017. Do entendimento de espólio resultam as seguintes consequências: uma mistura de arquivos como resultado de adições impróprias, a falta de controle sobre a preservação da autenticidade dos documentos, a ausência de representações arquivísticas e de vínculos arquivísticos, a tematização do arquivo em detrimento da descrição arquivística, a desarticulação entre coleções particulares e arquivos públicos e a não conformidade com padrões metodológicos compatíveis com um fundo fechado de arquivo. A Casa Fernando Pessoa é um lugar de convergência entre o material de museus, arquivos e bibliotecas. $\bigcirc$ resultado quantitativo total das representações dos manuscritos arquivísticos de Fernando Pessoa (1888-1935) corresponde ao número de 225 representações. Foram identificadas as seguintes categorias de representação: fac-similar, artística, visual, gráfica e digital. Identificou-se a ocorrência de 22 práticas distribuídas nos seguintes tipos: recriação histórica, exposição, exposição multimídia, curso, efemérides, webdifusão e curadoria digital. Foi possível constatar que a Casa Fernando Pessoa contribui para a democratização das representações dos manuscritos através de práticas de difusão e mediação cultural com material de arquivo.

PALAVRAS-CHAVE: Arquivos pessoais. Manuscritos. Representações. Casa-museu. Mediação cultural. Casa Fernando Pessoa.

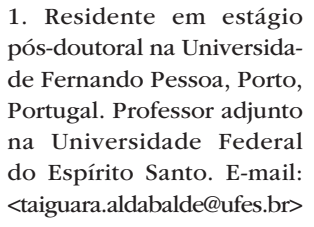

pós-doutoral na Universidade Fernando Pessoa, Porto, 
2. O termo "arquivos manuscritos" é adotado como similar aos termos "archival manuscripts" e "archivos manuscritos" localizados em Taylor (1972), Duff e Haworth (1990), Cook (1997), Farge (2009) e Bolofer (2015). Na Seção 4, o referido termo será arrolado na literatura arquivística.

3. A letra "s" sob o parêntese indica a qualidade plural em Pessoa por seus heterónimos ou "outros eus".
ABSTRACT: This article presents the results of a postdoctoral investigation. The research aims to discuss the understanding of the archival manuscripts of Fernando Pessoa as a spoil and to infer the quantitative representation of these documents, as well as to identify the practices through which these representations have been mediated in the Casa Fernando Pessoa. The documentary-historical method is adopted considering the products, the museum space, and the administrative documentation from 2006 to 2017 as the empirical basis. The following are the consequences of understanding the archive as a spoil: a mix of archives as a result of improper additions, a lack of control over the preservation of the documents' authenticity, absence of archival representations and archival bonds, the thematization of the archive in detriment of the archival description, the disarticulation between private collections and public archives and the no-compliance of methodological standards compatible with a closed archival fond. The Casa Fernando Pessoa is a place of convergence between museums', archives', and libraries' materials. The total quantitative result of the representations of the archival manuscripts of Fernando Pessoa (1888-1935) is 225 representations. The following categories of representation have been identified: fac-similar, artistic, visual, graphic, and digital. This research identified the occurrence of 22 practices distributed in these following types: historical recreation, exhibition, multimedia exhibition, course, ephemerides, webcast, and digital curation. It was possible to establish that Casa Fernando Pessoa contributes to the democratization of the manuscripts' representations through practices of diffusion and cultural mediation with archival material.

KEYWORDS: Personal archives. Manuscripts. Representations. House museum. Cultural Mediation. Casa Fernando Pessoa.

\section{INTRODUÇÃO}

A Casa Fernando Pessoa (CFP) é um órgão da administração pública que desenvolve parcerias com firmas privadas, unidades de investigação, entidades internacionais e atualmente está vinculada à Empresa de Gestão de Equipamentos e Animação Cultural (EGEAC) da Câmara Municipal de Lisboa (CML). Dentre as atribuições particulares da CFP se encontram a promoção da obra e o tratamento de parte do dito "espólio" de Fernando António Nogueira Pessoa (Lisboa, 13 de junho de 1888 - Lisboa, 30 de novembro de 1935) e dos seus "outros eus". No contexto dessas atividades é que a CFP tem sido um espaço de práticas que medeia representações dos arquivos manuscritos ${ }^{2}$ de Pessoa(s). ${ }^{3}$

A CFP é legalmente responsável por documentos autógrafos, pela biblioteca pessoal com anotações manuscritas e por um subconjunto dos arquivos de Pessoa(s), 
tais como cadernos, notas, recordações, identidade, contratos, títulos de arrendamento, certificados e o manuscrito da última frase ${ }^{4}$ do escritor. Esses documentos, por sua vez, são entendidos como parte de um espólio e reconhecidos como tesouro nacional, ${ }^{5}$ de maneira que se encontram dispersos em coleções. Mesmo os originais de uma única obra, como o Livro do desassossego, não estão sob uma mesma custódia, como indica a seção intitulada "Documentos que não se encontram na BNP". " Há uma concentração do acervo na Biblioteca Nacional de Portugal (BNP), onde uma parte significativa permanece sem tratamento e é desconhecida do público, pois:

a verdade é que a maior parte da narrativa de Fernando Pessoa continua inédita. Nem está sequer feito o levantamento dos originais, entretanto dispersos, e pela razão simples de que é tarefa difícil, exigente, morosa e frustrante. [...] Em 2009, podemos dizer que 90\% da obra narrativa de Pessoa continua desconhecida.?

A persistência de uma custódia no sentido estrito de guarda, quando poderia significar amparo legal, não leva os arquivos aonde quer que os públicos estejam, com as linguagens compatíveis com as culturas dos respectivos públicos, sendo assim uma forma de confisco do arquivo. ${ }^{8}$ Este ocultamento se reforça na medida em que uma elite acadêmica é tida como a razão de ser de uma instituição pública, e essa segregação intelectual pode se aprofundar quando se dividem os arquivos por nichos do saber. Nesse contexto é que os arquivos de Pessoa(s) estão sendo entendidos como espólios agenciados por atores dos saberes que condicionam as práticas e os conceitos em torno do tratamento da documentação. A noção de "arquivos literários" é considerada na arquivística tradicional como uma contradição em termos, ${ }^{9}$ pois a reunião sob a lógica temática de um conjunto de documentos ligados à literatura pessoana desrespeita o princípio da proveniência, e a proveniência dos arquivos literários não é outra senão o próprio escritor. ${ }^{10}$ No espólio pessoano da BNP estão contidos documentos alheios ao produtor, como textos de estudiosos da obra de Fernando Pessoa.

Se entendido a partir da abordagem funcional, o arquivo literário poder ser considerado como o conjunto documental de diferentes tipos que registram a prática da escrita do produtor durante o processo de criação ou processo genético " ' em determinados contextos. A organização britânica denominada "The Group for Literary Archives and Manuscripts" assinala que os arquivos literários são constituídos tipicamente por cartas, diários, documentos legais, registros econômicos, fontes impressas, diários e manuscritos literários, com esses últimos sendo identificados nos seguintes ciclos: a) pré-composição: listas, marginálias, rabiscos, planos de trabalho, anotações, esboços, cadernos, desenhos e notas;
4. O original documenta: "I know not what tomorrow will bring". Uma tradução possível para o português é a sentença: "Não sei o que o amanhã trará”.

5. Portugal (2009, p. 63126313).

6. Pizarro (2013, p. 521).

7. Gomes (2009, p. 49).

8. Cf. Jammet (2007).

9. Lodolini (2013, p. 21).

10. Cf. Cavalheiro; Rodriguez (2013).

11. Cf. Duarte (2007). 
12. Group For Literary Archives and Manuscripts (2011).

13. Riso (2015). b) composição: rascunhos encapelados, registros retrabalhados e cópias finais de manuscritos após todas as correções; c) pré-publicação: revisão, reconsideração e reelaboração do manuscrito e manuscrito definitivo; d) póscomposição: cópia para impressão de teste do autor e do editor, comprovativos e outros registros de produção; e el pós-publicação: as edições anotadas pelo autor sobre o próprio trabalho publicado. ${ }^{12}$

No caso português, a noção de arquivo literário parece indissociável do entendimento de espólio literário, que foi institucionalmente consolidado, dentre outras formas, com a implantação da Área de Espólios na BNP, entre os anos de 1981 e 1986, e isso significou, em termos práticos, a custódia sem respeito aos vínculos arquivísticos dos manuscritos de 36 autores diferentes incluindo Antero de Quental (1842-1891), Eça de Queirós (1845-1900), Antônio Feijó (1 859-1917), Cesário Verde (1855-1886), Fernando Pessoa (1888-1935) e Mário de SáCarneiro (1890-1916). O entendimento de espólio da BNP é mantido e reproduzido pela CFP até os dias de hoje, como é possível verificar nos termos da atual gestora Clara Riso:

Há uma ponte natural que une a Casa Fernando Pessoa à Biblioteca Nacional de Portugal: se encontramos na BNP os manuscritos, os cerca de 27.000 papéis do escritor Pessoa, é aqui na Casa Fernando Pessoa que guardamos a sua contraparte: os livros escolhidos por Pessoa leitor. A esta circunstância acresce um elemento fundamental: tecnicamente chamada marginalia, encontramos, em muitos desses livros, notas, comentários, interrogações ou até um poema inteiro. Pessoa traduzia, sublinhava, escrevia à margem o que raciocínios, personagens e palavras de outros despoletavam no seu próprio pensamento e na sua prática de escrita. Em 2010, uma equipa internacional de investigadores, coordenada por Jerónimo Pizarro, Patricio Ferrari e Antonio Cardiello, no âmbito de uma colaboração protocolada entre a Casa Fernando Pessoa e o Centro de Linguística da Universidade de Lisboa, conseguiu terminar a digitalização integral da biblioteca particular de Pessoa. Desde essa data, o conjunto de livros que pertenceu ao autor encontra-se on-line, acessível a partir de qualquer ponto do mundo. Só desta forma se assegura a permanência de um espólio que os anos vão acabar por apagar, e só assim se permite que circule e seja lido noutras geografias. ${ }^{13}$

Haja vista o entendimento do arquivo de Pessoa(s) como espólio incompatível com o princípio da proveniência e o conceito de arquivo literário tomado em perspectiva não funcional, a investigação problematiza a disjunção entre o entendimento de espólio em relação ao processamento arquivístico, uma vez que:

os documentos acumulados por indivíduos ao longo de sua existência nem sempre são tratados de modo coerente com a teoria arquivística, depois que ingressam em entidades de custódia. $\bigcirc$ fato de não haver, entre nós, palavra específica para designá-los (como 
manuscripts, personal papers, écrits personnels, carte personali, espólios e tantas outras) e, consequentemente, distingui-los dos arquivos institucionais, não resultou, na prática, na adoção de procedimentos comuns, nem impôs o reconhecimento dos atributos que permitiriam vê-los como conjuntos orgânicos e autênticos, marcadamente representativos das atividades que thes deram origem. [...] Mesmo quando se reconhece que "cada espólio é um caso particular, devendo o modelo organizativo tentar responder, na medida do possível, à sua peculiaridade", as soluções praticadas desmentem o bom propósito. $\bigcirc$ tratamento dado ao arquivo do escritor português David Mourão-Ferreira (1927-1996) é exemplo típico desse fenômeno. ${ }^{14}$

É razoável conjecturar que a própria concepção de espólio pode abarcar a mutilação dos fundos entre variadas instituições de custódia e coleções particulares. No tocante à distinção da CFP dos demais custodiadores, sublinhase o seu pertencimento à categoria de casa-museu. Essa, por sua vez, pode ser representada no Conselho Internacional de Museus pelo Comitê Internacional para Casas-Museus (CICM), incumbido de agenciar as diversas matérias de interesse dos membros. Portanto, entende-se a CFP aqui como um lugar de memória, não "uma unidade museológica acerca de uma pessoa, mas sim de um museu acerca de uma obra". ${ }^{15}$

Essa obra está materializada em fragmentadas coleções quando poderia/ deveria constituir um fundo fechado de arquivo. Tendo em vista que parte do espólio inclui materiais diversos, nota-se que a CFP tem sido um lugar onde a mediação é evidenciada como um campo de convergência entre os materiais tradicionais de museus, arquivos e bibliotecas.

Apesar da considerável atuação da CFP e do reconhecimento legal dos manuscritos pessoanos como espólio pelo Decreto-Lei n² $21 / 2009$, não se encontrou material bibliográfico sobre o tema. Também não há registros de estudos arquivísticos sobre o espólio pessoano nem referências na Pessoana, ${ }^{16}$ obra que sistematiza toda a bibliografia passiva, seletiva e temática associada a Pessoa. Pesquisou-se também na biblioteca mantida pela CFP, mas não há um livro, artigo ou escrito dedicado aos arquivos manuscritos pessoanos e a temática eleita. Isso é relevante, porque se trata da biblioteca mais especializada em Pessoa da Europa e do mundo.

É precisamente pela falta de estudos sobre o tema e por ter em vista a contribuição para os campos de pesquisa da mediação cultural com arquivos, ${ }^{17}$ arquivos pessoais, arquivos literários e arquivos de museus ${ }^{18}$ que esta investigação foi considerada necessária. Destaca-se que a mediação cultural foi estabelecida como campo de pesquisa interdisciplinar a partir de 1975, como decisão da assembleia instaurada na Seção 71 do Conselho Nacional das Universidades na França ${ }^{19}$ e é atualmente definida da seguinte forma:
14. Camargo (2009, p. 31)

15. Leão; Lira (2010, p. 344).

16. Blanco (2009).

17. A mediação cultural com arquivos é aqui entendida como o processo cujos objetos são representações de documentos arquivísticos tendo em vista a circulação, a recepção, a apropriação, a produção de ideias e produtos e a realização de práticas que contribuam para a democratização do patrimônio documental e da cultura arquivística.

18. Gilliland; McKemmish; Lau (2017, p. 24).

19. Cf. Mairesse (2016). 
20. Royal School of Library and Information Science (1999).

21. A tradução de archival research corresponderia ao termo "pesquisa arquivística”, porém essa expressão não foi encontrada no sentido de uma metodologia, e assim optou-se por manter a forma na língua inglesa.

22. Ver Jackson (2015, p.105).

23. Ayers et. al. (2007).

24. Huang; Bernhardt (2014).

25. Frisch (2012).

26. Stichelbaut (2015).

27. Bellofiore; Carter (2014).

28. Moore et. al. (2016)

29. Um exemplo de ferramenta desenvolvida para este método pode ser encontrado em Harvard University (2017).
Cultural Mediation is a collective term which, in its broadest sense, covers research into the organization and practices of cultural institutions as well as their political settings. Thus, on the one hand, research within Cultural Mediation focuses on e.g. the institutional implications of a growing collaboration between museums, libraries and archives (so-called MLA-institutions), and on the other hand, it is concerned with culture and cultural heritage as concepts that reflect a society's issues of identity and current political, ideological climate. ${ }^{20}$

O objetivo da investigação é discutir o entendimento dos arquivos manuscritos de Fernando Pessoa como espólio e levantar o quantitativo de representações desses documentos, assim como identificar as práticas através das quais essas representações têm sido mediadas na instituição municipal de custódia denominada "Casa Fernando Pessoa". Em outras palavras, busca-se conhecer os desdobramentos de um entender que aloca os arquivos na categoria de espólio, considerando as consequências disso. Sem perder de vista o agenciamento dos arquivos manuscritos para além do espaço de guarda e armazenamento, pretendese quantificar as representações dos arquivos mediadas no contexto das práticas, dos produtos e do espaço da Casa Fernando Pessoa, assim como identificar as práticas de difusão e mediação cultural.

\section{PERCURSO INVESTIGATIVO}

Adotou-se primeiramente a pesquisa bibliográfica e, em uma segunda etapa, uma investigação histórico-documental quali-quantitativa com a instrumentalização de archival research. ${ }^{21}$ É fundamental sublinhar que a archival research é um tipo de pesquisa descritiva com fontes primárias, especificamente com uso dos materiais de arquivo, ${ }^{22}$ adotada em diversas áreas, como medicina, ${ }^{23}$ ciências jurídicas, ${ }^{24}$ ciência política, ${ }^{25}$ história, ${ }^{26}$ economia ${ }^{27}$ e ciências sociais. ${ }^{28}$ Além disso, nota-se que não há uma obra em língua portuguesa com uma sistematização do método archival research que abarque as técnicas, as ferramentas ${ }^{29} \mathrm{e}$ as possibilidades de estudos. Em que pese a falta desta referência na língua vernácula, optou-se pelo referido método com ampliações, pois a base empírica correspondeu aos documentos e registros arquivísticos das práticas e, posteriormente aos produtos culturais e aos espaços da casa-museu. Isso porque inicialmente foi prevista a coleta de dados apenas nos documentos administrativos da CFP, pois estes refletem as suas atividades e consequentemente as suas práticas de mediação cultural com representações dos arquivos manuscritos. Constatou-se que os produtos da CFP também eram fontes incontornáveis na investigação, portanto, estes foram considerados material de análise. Soma-se a isso a relevância 
do lugar, dos espaços e das ambiências da própria casa-museu, que também serviram como fontes para a pesquisa pelo mesmo motivo.

A primeira etapa correspondeu à pesquisa bibliográfica, incluindo páginas institucionais na internet, como a homepage da CFP. Ainda nesse momento se destaca a Biblioteca da Casa Fernando Pessoa como a principal referência. Teoricamente optou-se por trabalhar a partir da perspectiva histórico-cultural para a representação. ${ }^{30}$ Portanto, as representações são aqui entendidas como instrumentos de um conhecimento mediato que remetem às ideias de coisas ausentes, de forma que esses objetos distantes podem ser conhecidos pelos sujeitos mediante signos que os representam. ${ }^{31}$

Cabe apontar que, se os instrumentos de pesquisa podem ser considerados como instrumentos de representação ${ }^{32}$ que agenciam entendimentos sobre e a partir dos documentos, então é possível presumir que há uma relação entre as representações arquivísticas como produtos da descrição e as representações categorizadas no âmbito dos usos culturais da CFP. Nessa perspectiva a descrição não é uma prática técnica isolada, mas está inserida num contexto em que há um nexo entre as escolhas dos agenciadores na representação dos documentos e os usos dos arquivos.

A identificação dos tipos de práticas foi embasada na lógica classificatória das atividades em arquivos. ${ }^{33}$ Também nesta fase levantou-se as fontes de conhecimento sobre o entendimento do espólio e seu tratamento documental, e a partir disso analisaram-se, à luz da teoria arquivística tradicional ${ }^{34}$ e do multiverso arquivístico, ${ }^{35}$ aqueles procedimentos e saberes vinculados ao dito "espólio pessoano".

Em um segundo momento, procedeu-se à coleta de dados e à análise documental segundo o método archival research. Dentre as espécies e tipos documentais se destacaram: folders de lançamentos de exposições e livros, dossiês dos projetos, catálogos das exposições, folhetos, programas, planos de ação, fotografias, dossiês de eventos, normas internas, legislação pertinente à CFP e ao dito "espólio pessoano", correspondências e registros de intervenções na estrutura e nos ambientes da CFP. Encontraram-se registros com representações dos arquivos manuscritos de Pessoa nas práticas registradas na documentação administrativa, nos produtos da CFP e no próprio espaço da casa-museu.

Um dos desafios dessa fase foi o acesso à documentação, pois o contato com as fontes primárias foi gradativo e parcial, ditado pelo ritmo de cooperação das instituições públicas e seus funcionários. Cabe destacar que a Lei de Acesso aos Documentos da Administração (Lei n 46/2007 de 24 de agosto) busca garantir o acesso aos documentos, de modo que é direito de todo cidadão português acessar os registros da administração pública.
30. Cf. Chartier (2002).

31. Cf. Chartier (2011)

32. Cf. Rodrigues (2003).

33. Cf. Vela (2001)

34. Cf. Lodolini (2013).

35. No âmbito da unidade investigativa "Archival Education and Research Initiative" da Universidade da Califórnia (UCLA), Anne Gilliland (2017) situa o paradigma do multiverso arquivístico no entendimento de que o mundo é construído com o outro em múl tiplas formas de saberes $e$ práticas, de diferentes narrativas que podem coexistir em um mesmo espaço. 
A esse respeito arrolamos as seguintes notas do percurso investigativo: a data inicial da investigação correspondia ao ano de 1993, quando a CML inaugurou o espaço, porém a documentação de 1993 até 2005 foi recolhida para $\circ$ Arquivo Municipal de Lisboa (AML), que não viabilizou o acesso. A alegação do AML é de que o depósito correspondente ao armazenamento do material de arquivo da CFP no período de 1993 a 2005 não está acessível. É preciso salientar que o principal objetivo de uma instituição de arquivo deveria ser, em tese, prover o acesso aos documentos custodiados, e, portanto, considera-se que tal argumento não é compatível com a razão de ser da instituição.

Nota-se ainda que o AML não recolhe a documentação de arquivo dos órgãos municipais, porque as repartições públicas não estão compulsoriamente dadas a isso e facultam a transferência apenas voluntariamente. Assim, cada unidade administrativa tem um acordo distinto com a divisão, de maneira que não há uma política pública de gestão documental. Verifica-se que há critérios antiarquivísticos nos procedimentos de destinação final, pois, após avaliação, os arquivos permanentes são artificialmente recolhidos ao AML a partir de "vocações" para um determinado gênero e tipo documental. Para o AML, há três vocações: (1) arquitetura: há um núcleo do bairro de Campo Grande que restringe a recolha e acesso a tipos documentais como plantas arquitetônicas de edifícios históricos e outras associadas a essa temática; (2) fotografia: num outro núcleo o foco é voltado ao gênero fotográfico, e para aqueles que só conhecem este espaço é possível que se venha fazer uma confusão entre um arquivo público municipal e uma hemeroteca; (3) audiovisual: trata-se de outra "vocação" do AML que se assemelha à restrição de gênero documental e o agrupamento de coleções sem levar em conta os princípios arquivísticos. Isto posto, inicialmente os documentos administrativos da CFP não foram nem sequer considerados para consulta porque o $\mathrm{AML}$ se orientava por essas ditas "vocações". A ocultação de fontes primárias reforça a opção por investigar o tema a partir dos registros arquivísticos como forma de valorizar os documentos e observar as políticas públicas de arquivo ou a falta dessas como um fenômeno subjacente.

Com base na Lei n 46/2007 apresentou-se uma queixa junto à Comissão de Acesso aos Documentos Administrativos (Cada) para dar prosseguimento à análise do material previsto para o desenvolvimento da investigação. A Cada, por sua vez, está subordinada à Assembleia da República e tramita o Processo $n^{\circ}$ 656/2016, referente a essa investigação. Frente à inacessibilidade aparentemente injustificada das fontes primárias de 1993 a 2005, considerou-se a classe das representações digitais como objeto da investigação e, portanto, alargaram-se as perspectivas. A ampliação dos horizontes investigativos está fundamentada nas 
seguintes linhas de pesquisa: as convergências com humanidades digitais, tipos de instituições arquivísticas e diversidade dos paradigmas arquivísticos. ${ }^{36}$

As fontes primárias a partir das quais os resultados foram obtidos estão sob a custódia da CFP e abrangem o período de 2006 a janeiro de 2017 . Salienta-se que um documento do ano de 1995 foi encontrado num dossiê de projeto da CFP. Os documentos administrativos foram analisados para fins de inferência quantitativa e para identificação dos tipos de práticas culturais com representações dos arquivos manuscritos pessoanos. Foram excluídas as representações encontradas de arquivos manuscritos de outros autores, tais como Clarice Lispector (1920-1977).

$\bigcirc$ enquadramento dos manuscritos como patrimônio português (Lei n. $13 / 1985$ ) foi relevante para a pesquisa, pois a partir disto foi possível reconhecer a inerência dos seguintes valores dos arquivos manuscritos: ${ }^{37}$ valores cognitivos, valores formais/estéticos, valores afetivos e valores pragmáticos. Esse ponto de vista é significativo, pois as representações dos arquivos manuscritos foram entendidas como decorrentes do uso dos arquivos para vários fins (por exemplo, a publicidade, a criação artística e fins comerciais ${ }^{38}$ no contexto de práticas que enfatizam determinados valores e definem as qualidades das representações. A partir de características próprias e dos valores identificados, as representações foram categorizadas nas seguintes classes: (1) representações digitais; (2) representações fac-similares; (3) representações artísticas; (4) representações gráficas; e (5) representações visuais. A caracterização das classes será tratada na seção específica dos resultados que, por fim, foram agrupados num gráfico de dispersão que registra os dados quantitativos através de uma série temporal. Os tipos de práticas identificados também foram sistematizados com base em Aldabalde (2015).

\section{A CASA FERNANDO PESSOA: CARACTERIZAÇÃO}

Considerando que a criação da CFP ocorreu em função do legado de Fernando Pessoa, julga-se necessário fazer apontamentos sobre a personagem histórica, que é retratada da seguinte maneira: "Ele é hoje o principal elo literário de Portugal com o mundo. [...] é mais plural que se possa imaginar [...] materializa inúmeros interesses e representa um autêntico patrimônio coletivo: do autor, das diversas figuras autorais inventadas por ele e dos leitores". 39 Pessoa nasceu em Lisboa e aos cinco anos perdeu o pai, que morreu de tuberculose. Sob a custódia da mãe, se mudou para Durban, na África do Sul, onde estudou em uma escola de língua inglesa administrada por freiras católicas irlandesas. Ao regressar a Portugal em 1905, Pessoa começou o curso na Universidade de Lisboa, quando
36. Cf. Gilliland; McKemmish; Lau (2017, p. 23-24).

37. Cf. Meneses (2010).

38. Cf. Pizarro; Ferrari (2016, p. 733).

39. Pizarro; Ferrari (2016, p. 733). 
40. Bloom (2005).

41. Cf. Vila Maior (1994).

42. Rita (2016, p. 602). passou a ficar conhecido pela prosa, poesia e traduções. $\bigcirc$ poeta é considerado por Harold Bloom um dos 26 escritores responsáveis por estabelecer os parâmetros da literatura ocidental. ${ }^{40}$ Pessoa não era apenas um poeta distinto, mas também um escritor multifacetado que se debruçou sobre temas como arte, filosofia, política, sociologia e metafísica. Além disso, como autor, caracterizou-se por seus heterônimos e por transpor a relação entre autoria e individualidade, antecipando assim a fragmentação do self, uma das questões do pós-modernismo. Essa fragmentação é a marca indelével da obra pessoana, pois sua originalidade está centrada nos heterônimos, que foram sustentados com veracidade, credibilidade e autonomia, como somente Pessoa foi capaz de fazer. ${ }^{41}$

Posto isso, há que se ponderar sobre alguns aspectos do processo histórico que definiram os contornos funcionais da CFP e particularmente as circunstâncias que contribuíram para a formação do acervo da casa-museu. Ao encontro disso, situa-se que em 1985 ocorreram as celebrações de cinquenta anos da morte de Pessoa. Neste ano o autor foi traduzido para quarenta idiomas, e um expressivo número de edições foi lançado. $O$ corpo do poeta foi levado para o claustro do mosteiro dos Jerônimos, onde estão depositados os restos mortais da mais alta elite portuguesa, nomeadamente a nobreza e membros da realeza. No ano posterior, marco da redemocratização de Portugal, o presidente civil Mário Soares (19242017) chegou ao poder após 60 anos de regimes ditatoriais. Cabe lembrar que, em 1926, o golpe militar colocou a então recente República Portuguesa nas mãos dos generais que submeteram o país a um regime de austeridade econômica sob o comando de Salazar (1 889-1970). No período da redemocratização, pode-se considerar que Fernando Pessoa foi um símbolo da luta democrática e da resistência ao salazarismo. A conversão de Pessoa num símbolo antissalazarista foi possível, dentre outros motivos, graças a um acontecimento de 1934, quando o poeta faltou deliberadamente à cerimônia na qual foi condecorado com o Prêmio Antero de Quental, realizada pelo Secretariado da Propaganda Nacional (SPN). O SPN, criado em 1933, deu lugar, em 1945, ao Secretariado Nacional de Informação (SNI), que teve um papel fundamental na concepção [...] e divulgação de um ideário nacionalista no Estado Novo". ${ }^{22}$ A falta proposital de Pessoa é atribuída ao fato de que Salazar entregaria os diplomas aos vencedores e, como se soube através dos escritos antissalazaristas publicados a partir de 1974, o poeta era avesso à figura do ditador, registrando as seguintes críticas:

Salazar tem, em altíssimo grau, as qualidades secundárias da inteligência e da vontade. É o tipo do perfeito executor da ordem. [...] Quando muito na escala da governação pública poderia ser o mordomo do país. [...] entre os conflitos das doutrinas, não sabe decidir-se [...] $\bigcirc$ Chefe de governo não é um estadista: é um arrumador [...] É sempre e em tudo um contabilista, mas só um contabilista. Quando vê que o país sofre, troca as rubricas e abre novas contas. Quando sente 
que o país se queixa, faz um estorno. A conta fica certa. $\bigcirc$ Prof. Salazar é um contabilista. A profissão é eminentemente necessária e digna. Não é, porém, profissão que tenha implícitas diretivas. Um país tem que governar-se com contabilidade, não pode governar-se por contabilidade. Assistimos à cesarização de um contabilista. Um cadáver emotivo, artificialmente galvanizado por uma propaganda... Duas qualidades the faltam - a imaginação e o entusiasmo. Para ele o país não é a gente que nele vive, mas a estatística d'essa gente. Soma, e não segue. ${ }^{43}$

Não é por acaso que a imagem de Fernando Pessoa figurou numa das faces das cédulas de cem escudos, que tinham na outra face uma rosa vermelha - um dos símbolos do Partido Socialista (de 1973 até a atualidade), que chegaria ao poder pela primeira vez justamente em 1986, quando as notas foram emitidas -, e isso poderia significar que Pessoa era ou ainda é um símbolo de um Portugal democrático.

Nesse panorama, em 1986 a CML adquire os livros de Pessoa com 1. 161 volumes e manuscritos anotados, já tendo em vista um projeto embrionário que daria origem à CFP. Ora, o acervo em questão corresponde a uma parte significativa da materialidade da literatura de Fernando Pessoa, pois suas particularidades de criação e suas opções criativas (por exemplo, escolha de leituras, instrumento de escrita, cor da tinta, forma da letra, papel e variedades da utilização do livro como superfície de escrital foram fisicamente manifestadas nos seus materiais. A responsabilidade dos custodiadores é preservar as evidências físicas e o sentido original dos registros, pois os arquivos são cultura material e expressões físicas da cultura em que foram produzidos e utilizados, e os custodiadores influenciam as futuras significações dos documentos através de suas escolhas. ${ }^{44}$ Logo, não é mera eventualidade que esses documentos ocupam uma posição de destaque para a CFP. Acrescenta-se que, sem prejuízo para as funções burocráticas ou oficializadas, a CFP possui, enquanto instituição de custódia, a responsabilidade de tratar o material de acordo com suas especificidades.

É razoável reputar a origem da CFP à Associação Pessoana dos Amigos do Martinho da Arcada (APAMA), que, ao expressar a vontade coletiva de colocar uma placa em homenagem a Pessoa na frente do imóvel, ${ }^{45}$ engendrou o processo de classificação do edifício ocupado hoje pela casa-museu. A APAMA nasceu em 1987, quando era um movimento de defesa da preservação do Café Martinho da Arcada. A mesma associação impediu a demolição do edifício onde hoje é a CFP com um comunicado à Câmara de Lisboa em 1988, que levou ao processo de classificação do edifício como de interesse público. Atualmente a CFP é um espaço da identidade, da memória e da obra pessoana. A própria casa-museu é uma representação simbólica ${ }^{46}$ que tem acrescido valor ao bairro de Campo de Ourique, projetando-o à cena cultural e para além das fronteiras /atribuímos essa 
projeção no estrangeiro ao objetivo dum projeto de internacionalização da obra e imagem de Pessoa). O projeto inicial da CFP foi inaugurado em 1993 pelo Departamento de Cultura da Câmara de Lisboa através do despacho $n^{\circ}$ 79/P/1994 da CML, que definiu as seguintes funções: (1) promover a obra de Fernando Pessoa e estimular a poesia; (2) assegurar o tratamento do espólio de Fernando Pessoa; (3) apoiar e realizar edições e publicações para divulgar a obra de Fernando Pessoa e a poesia; (4) incentivar e apoiar atividades de pesquisa no campo de estudos pessoanos em universidades e outras instituições; (5) promover a investigação e difundir o conhecimento da obra de Fernando Pessoa internacionalmente através das novas tecnologias; (6) organizar iniciativas culturais em colaboração com outras entidades públicas e privadas.

No tocante à estruturação da casa, dois anos após a criação da CFP foi designada uma equipe com dez pessoas para realizar as atividades, e em outro despacho, registrado sob o número 228/P/ 1996, a Câmara de Lisboa tratou dos aspectos funcionais que definem a CFP como espaço cultural polivalente, lugar de convergência entre materiais de arquivo, biblioteca e museu. A CFP passa então a adquirir e atualizar livros, formando a mais relevante biblioteca especializada em Fernando Pessoa do mundo. A CFP também se consolidou como lugar de mediação com as instituições internacionais de pesquisa e o setor da cultura. Os dois despachos oficias da CML destacam a necessidade de cultivar uma conexão com a Biblioteca Nacional com vistas a parcerias em relação ao espólio de Pessoa através de parcerias com unidades internacionais de investigação, entidades públicas e privadas. Em se tratando da possibilidade de parceria para exploração, enquanto uso múltiplo dos arquivos, é possível observar usos em diversos domínios: acadêmicos, tecnológicos, artísticos, administrativos e comunicativos. ${ }^{47}$

A CFP está continuamente valorizando os livros de Pessoa, mantendo ainda um fundo de poesia portuguesa e internacional, uma biblioteca com edições nacionais e estrangeiras das obras de Pessoa, uma coleção de livros com temas associados a Pessoa e sua obra, um banco de dados online de poesia e um site com acesso gratuito aos documentos digitalizados. Além disso, há diversos documentos custodiados pela CFP que estão ou estiveram em exposições de museus. Observou-se que não há no organograma da CFP um arquivo, porém há uma funcionária ativa nas exposições, eventos e atividades, com especialização em arquivos e capaz de responder também pelos documentos administrativos. Essa ausência de um arquivo e de uma política de gestão para os próprios documentos que a CFP produz enquanto órgão público é, ou pode ser, em certa medida, o reflexo da inoperância do AML como órgão que define as políticas arquivísticas para a cidade de Lisboa. 
A organização administrativa da CFP foi integrada à Direção Municipal de Cultura através do Departamento de Cultura, quando a gestão foi entregue a Manuela Júdice (1993-1999), sucedida por Rita Rodrigues (2000-2002), até que se definiu o nome de Clara Ferreira Alves (2002-2006) para a direção dessa repartição pública. Sucederam-se ainda Francisco José Viegas (2006-2008), Inês Pedrosa (2008-2014) e Clara Riso (2014 - presente). Essas gestões têm em comum um ponto: dar continuidade ao projeto de internacionalização da CFP. Como resultado exitoso dessa continuidade, observa-se no relatório de 2014 a presença de diversas e numerosas nacionalidades de visitantes. Organizadas por ordem crescente tem-se: brasileiros, italianos, franceses, alemães, belgas, espanhóis, dinamarqueses, colombianos, finlandeses, argentinos, mexicanos, canadenses, venezuelanos, suecos, ingleses e tchecos - e ainda há registro de visitantes japoneses, americanos, chilenos e sul-africanos. Atualmente, a internacionalização continua em curso principalmente por meio de eventos e exposições em vários países, como França, Espanha e Estados Unidos. Destacamos as seguintes casas-museu e casas de poesia estrangeiras que têm mantido relações institucionais com a CFP: La Casa-Museo Federico García Lorca (Granada, Espanha), Casa Rómulo Gallegos (Venezuela), Maison de la Poesié d'Amey (Bélgica), Maison de la Poesié de Paris (França), Poets House (Nova lorque) e Hölderlin-Haus (Tubigen, Alemanha).

A concepção da CFP como projeto de internacionalização é condizente com o interesse pelos arquivos manuscritos de Pessoa, que está para além de Portugal. Os brasileiros, por exemplo, estão entre os principais públicos porque, dentre outros motivos, possuem a língua e a história em comum com os portugueses. Um indicador da relevância dada ao legado pessoano é seu espaço na imprensa brasileira. Em 16 de janeiro de 2016, o jornal Folha de São Paulo48 publicou uma reportagem sobre a descoberta de arquivos manuscritos de autoria de Pessoa, enfatizando o espólio associado ao literato, com destaque para um manuscrito de mais de 2 mil páginas. Somado à repercussão na mídia, há um impacto da obra pessoana para a economia cultural do Brasil, pois Pessoa está presente em empreendimentos editoriais e artísticos. Um exemplo disso é o repertório da cantora de música popular brasileira Maria Bethânia. No álbum "Maricotinha ao vivo" de 2002, o "Poema do Menino Jesus" de Alberto Caeiro ocupa a faixa 23. Outro registro da cantora é encontrado no álbum "Dentro do mar tem rio (ao vivo)", de 2007, na faixa 33, com a seguinte adaptação do texto "Ultimatum", que tem circulado intensamente desde 2016 nas redes sociais no Brasil:

Mandato de despejo aos mandarins do mundo/ Fora tu,/ reles/ esnobe/ plebeu/E fora tu, imperialista das sucatas/Charlatão da sinceridade/ e tu, da juba socialista, e tu, qual- 
49. Bethânia (2008).

50. Vila Maior (2011).

51. Cf. Lopes (1985)

52. Cf. Empresa de Gestão de Equipamentos e Animação Cultural (2015, p. 24).

53. Association of Independent Museums (2002). quer outro/ Ultimatum a todos eles/ E a todos que sejam como eles/Todos! Monte de tijolos com pretensões a casa/Inútil luxo, megalomania triunfante/ E tu, Brasil, blague de Pedro Álvares Cabral/ Que nem te queria descobrir/ Ultimatum a vós que confundis o humano com o popular/ Que confundis tudo/Vós, anarquistas deveras sinceros/ Socialistas a invocar a sua qualidade de trabalhadores/ Para quererem deixar de trabalhar/Sim, todos vós que representais o mundo/ Homens altos/Passai por baixo do meu desprezo/ Passai aristocratas de tanga de ouro/ Passai frouxos/ Passai radicais do pouco/ Quem acredita neles? / Mandem tudo isso para casa/ Descascar batatas simbólicas/ Fechem-me tudo isso à chave/ $E$ deitem a chave fora/ Sufoco de ter só isso à minha volta/Deixem-me respirar/Abram todas as janelas/Abram mais janelas/ Do que todas as janelas que há no mundo/ Nenhuma ideia grande/ Nenhuma corrente política/ Que soe a uma ideia grão/ $\mathrm{E}$ o mundo quer a inteligência nova/ A sensibilidade nova/ $O$ mundo tem sede de que se crie/ Porque aí está apodrecer a vida/ Quando muito é estrume para o futuro/ $\mathrm{O}$ que aí está não pode durar/Porque não é nada/ Eu da raça dos navegadores/ Afirmo que não pode durar/Eu da raça dos descobridores/Desprezo o que seja menos/ Que descobrir um novo mundo/ Proclamo isso bem alto/ Braços erguidos/ Fitando o Atlântico/ E saudando abstratamente $\circ$ infinito. ${ }^{49}$

Esse texło foi objeto de diversos estudos, como "Do Ultimato ao Ultimatum: a vitalidade nacional". ${ }^{50}$ É possível tomar a prosa panfletária assinada por Álvaro de Campos como um monólogo dramático ${ }^{51}$ e foi uma colaboração para a revista Portugal Futurista, lançada no ano de 1917. Além da presença na indústria fonográfica e outras indústrias culturais que promovem a circulação das ideias contidas nos documentos, a obra pessoana encontrou lugar nos aparelhos culturais brasileiros, como no Museu da Língua Portuguesa. Isso nos permite pensar os arquivos manuscritos de Pessoa e as representações desses documentos como partes dos patrimônios materiais e imateriais lusófonos mediados pela CFP. O papel de mediação da CFP é reforçado no Instrumento de Gestão Provisional de 2015, emitido pela EGEAC, que define a mediação do público com necessidades especiais e as situações de exclusão como uma das responsabilidades sociais da repartição. $\bigcirc$ documento registra ainda: "Pretendemos promover uma estratégia global que coloque em foco questões de mediação e acessibilidade, para actuar de forma adequada, dirigida e interactiva. Os diferentes públicos serão considerados na sua especificidade". ${ }^{52}$ Soma-se a isso as atividades concernentes à biblioteca da CFP, que evoca a responsabilidade por programas de difusão do dito "espólio" e por atividades de mediação da leitura. Nesse sentido, o serviço educativo tem sido determinante nas linhas de atuação adotadas pela CFP. Apesar da casa-museu não ter publicado, ou publicizado, uma posição sobre o cuidado com as práticas que envolvem arquivos ou as representações dos arquivos manuscritos, essa preocupação vem sendo discutida em âmbito internacional, de modo que as diretrizes para as práxis foram elencadas no Código de Práticas com Arquivos para Museus de 2002.53 
Antes da apresentação dos dados quantitativos e qualitativos sobre o peso das representações dos arquivos manuscritos em produtos e práticas culturais da CFP, é incontornável discutir o entendimento do termo "espólio". A expressão tem sido adotada por museus e bibliotecas para designar os arquivos totais ${ }^{54}$ de pessoas que naturalmente produziram uma "diversidade de materiais reunidos sob a Categoria de 'Espólio Documental'", e que, por isso mesmo, reúnem uma "clara intersecção entre os trabalhos de inventário museológico, a biblioteconomia e a arquivística". ${ }^{55}$ No caso estudado, o termo "espólio" refere-se a fragmentos do que foi um único conjunto documental, isto é, o arquivo pessoal ou fundo fechado de Fernando Pessoa. A seguir discutem-se as consequências ou desdobramentos do entendimento dos arquivos como espólio.

\section{ARQUIVOS DE PESSOA(S): DISCUTINDO ENTENDIMENTOS E SEUS DESDOBRAMENTOS}

ano de 1986 está timbrado no instrumento de pesquisa cuja capa é marcada com a identificação "Espólio de Fernando Pessoa: Inventário. (BN. Esp. E3)". Esse inventário não foi publicado e está acessível apenas sob consulta presencial autorizada na Seção de Reservados da BNP em Lisboa. $\bigcirc$ documento possui uma introdução intitulada "Explicação", com o seguinte conteúdo:

O presente inventário do espólio de Fernando Pessoa é um sumário das descrições atribuídas aos diversos conjuntos de manuscritos do poeta pelo "Grupo de Trabalho" encarregado daquela tarefa por despacho ministerial de 05/11/69 foi dado por concluído em 1973 [...] $\bigcirc$ instrumento de referência que então vinha a lume compreendia o registro de cada fragmento, feito pelo título e começou pelo envelope correspondente a poesia assinada pelo heterónimo pessoano Charles Robert (env. 13, Op. Cit. P. 331 1). Não permitia, porém, qualquer visão de conjunto do acervo, sorte de retrato ao corpo inteiro do espólio. Sabia-se que a distribuição dos diversos manuscritos pelos diferentes "envelopes" [...] era devido ao "Grupo de Trabalho" encarregado da inventariação (grupo sempre oscilante de colaboradores), sem que se fosse perceptível o critério, ou critérios, adotados na ordenação, que também não vinham explicitados no citado volume das Bibliotecas e Arquivos de Portugal. Nalguns casos teriam correspondido a sinais do próprio poeta [...] noutros a "manchas temáticas" mais ou menos genéricas e arbitrárias construídas pelos catalogadores. [...] Continuava fazer-se sentir a falta de um guia ou inventário geral que permitisse ao investigador orientar seus passos entre a vastidão oceânica dos papéis pessoanos. Com este fim, procedeu-se à recuperação das informações inscritas em cada envelope do espólio, entretanto, abandonados como invólucros, pela respectiva ordem topográfica, isto é, pela ordem que haviam sido numerados (de 1 a 144D2 +15 in) e subnumerados (por letras $A, B, C \ldots$ ou expoentes $\left.271,27^{2} \ldots\right)$ pelos catalogadores. Assim o pesquisador encontrará pela ordem estabelecida pelo "Grupo de Trabalho" de 1969 a 1973 as referências relativas dos títulos, próprios ou atribuídos de cada conjunto, seguidas das quantificações de documentos [...] Nalguns casos foi aposta, posteriormente, uma nota relativa à microfilma-
54. Cf. Cook (2005).

55. Instituto dos Museus e da Conservação (2008, p. 5). 
56. Biblioteca Nacional de Portugal (1986, p. 2-6). gem, estado de conservação ou procedimento catalográfico em curso. Antecede o inventário um índice alfabético (dicionário) de autores, heterónimos e títulos, próprios ou atribuídos, de cada conjunto, auxiliar que acompanhava já o espólio a quando de sua entrada na Biblioteca Nacional. [...] Em 1981 iniciou-se com o propósito expresso de garantir a preservação do acervo, a microfilmagem integral do espólio, só concluída no decurso de 1986 computando o número de imagens obtidas, em ca.45000 (1 17 bobines). Na sua execução respeitou-se a sequência topográfica existente aproveitando para a identificação dos sucessivos conjuntos o recorte do envelope em que originalmente haviam sido agrupados. Na pesquisa através do microfilme deverá o utilizador ter em conta a ordem topográfica do inventário e dentro de cada conjunto a numeração original aposta no canto superior direito de cada fragmento. $O$ inventário cobre todo o acervo, sendo a totalidade dos documentos existentes [...] de 27.543, repartidos por 343 "envelopes" e assim classificados quanto a sua natureza: Originais de Fernando Pessoa - Autógrafos - 18.816.; Textos datilografados - 3948; Mistos - 2662; Cadernos - 29; Cópias de originais de Fernando Pessoa - 893; Originais de Terceiros [...] A impossibilidade de apresentar, em espaço de tempo útil, um inventário completo que possa adequadamente satisfazer as duas exigências fundamentais deste tipo de trabalho (rigor e celeridade) parece justificar que se coloque nas mãos do investigador, desde já um auxiliar de referência que sem prejuízo da catalogação a haver, indique alguns dos caminhos a seguir nessa verdadeira "floresta de enganos" que o espólio pessoano constitui. BN. Junho de 1986.56

Inicialmente deve-se atentar para o fato de que o dito "Grupo de Trabalho" fica sob o véu do anonimato, sem que existam referências aos nomes dos componentes no instrumento de pesquisa. É fundamental questionar a afirmação de que os documentos não permitiam uma perspectiva de conjunto, pois seria mesmo impossível aos catalogadores sistematizar o entendimento conjuntural dessa massa documental acumulada? Igualmente essencial é a contextualização desse documento, quando aponta que haveria na ocasião escassez de tempo para catalogar com rigor e celeridade um inventário completo, pois, se isso pode ter ocorrido, por outro lado passaram-se mais de trinta anos desde então, e esse espaço de tempo é suficiente para o cumprimento da responsabilidade ou, no mínimo, para publicização da sua continuidade em "tempo real", via web.

Igualmente sensível é a dúvida sobre as intencionalidades deste texto: trata-se de uma narrativa para justificar que a BNP não cumprisse sua atribuição de descrever as peças documentais? Durante o processo investigativo, quando foi levantado in loco o problema da falta de metadados básicos, como as datas dos arquivos, as funcionárias responderam em uníssono que esse era um trabalho para o pesquisador. De onde provém tal ideia? É possível considerar que a seção "Explicação" do "Espólio de Fernando Pessoa: Inventário" pode ter servido de pretexto para a inércia da catalogação de cada peça dos arquivos de Pessoa(s)? É certo que a resposta das funcionárias revela uma interpretação descontextualizada, pois o texto original foi produzido num momento histórico em que não havia tempo hábil para a 
inventariação completa dos documentos, de modo que o pesquisador poderia servir como auxiliar para contribuir para um quadro referencial sem supressão de uma catalogação a ser colocada em curso de 1986 até os dias atuais.

Assim, não há precedente que justifique a transferência de responsabilidade e a ausência de um catálogo dos arquivos de Pessoa(s) três décadas após o referido inventário. Não é fortuitamente que, em termos de controle, o Arquivo de Cultura Portuguesa Contemporânea (ACPC) da BNP preserva com enfoque na topografia o espólio pessoano, transferindo a responsabilidade da descrição/ identificação para o público especializado. Sequer o ACPC tem publicizado o tratamento documental com registros de contribuições dos investigadores para descrição, mantendo-se ultrapassado em relação a plataformas digitais de descrição colaborativa e edições críticas on-line, que se fazem urgentes para a democratização do patrimônio documental legado por Pessoa e guardado pela BNP.

documento "Espólio de Fernando Pessoa: Inventário" traz consigo o entendimento, comum à BNP e à CFP, que considera o acervo albergado um espólio. Em grande medida, isso também é, além de uma expressão institucional, uma consequência das referências oficiais que consolidaram o termo "espólio". Dentre os principais referenciais está a BNP, cujo entendimento de espólio, no âmbito do ACPC, foi agenciado pelo saber da chamada "arquivística literária". Mas o quanto há de arquivística na "arquivística literária"? Dentre as páginas de bibliografia de referência para "arquivística literária" encontram-se mais de 150 obras, apenas cinco de arquivística. ${ }^{57}$ Ademais, o próprio entendimento de espólio, nesse caso, está associado ao termo "arquivo literário", incutido na identidade do ACPC da BNP. Ora, não é possível criar um arquivo literário enquanto reunião temática ou coleções sem que haja uma contradição em termos, ${ }^{58}$ pois no entendimento de espólio a organicidade já não corresponde mais a um princípio teórico-metodológico de uma ciência aplicada. Portanto, sem o aporte arquivístico, os praticantes do espólio não são capazes de reconstituir os fundos segundo o princípio da proveniência e o princípio da manutenção da ordem original, de modo que aquilo que se perpetua é apenas a fragmentação e a ruptura com a própria lógica de constituição do produtor.

O que tem se chamado de "arquivo literário" é uma coleção de documentos tematizados. Por isso, é preciso sublinhar que o ato de colecionar não é sinônimo de acumular, pois na ação de colecionar existe a artificial seletividade, que por sua vez resulta de ações meramente facultativas (por exemplo, ninguém é obrigado por lei a comprar livros e ao mesmo tempo colecioná-los), enquanto na ação de acumular há razões compulsórias que fundamentam a cumulatividade (por exemplo, os documentos arquivísticos de identificação do cidadão são obrigatórios para que
57. Cf. Oliveira (2007, p. 383-397).

58. Cf. Lodolini (2013, p. 21). 
59. Portugal (2009, p. 6313).

60. Arquivo Nacional (2005).

61. Taylor (1972).

62. Duff; Haworth (1990).

63. Cook (1997).

64. Kurtz (2004).

65. Brem (2006).

66. Farge (2009)

67. Owens (2012)

68. Zas; Rodríguez; Rey (2014).

69. Bolofer (2015).

70. Goryaeva (2016).

71. Farge (2009, p. 22). se possa fazer valer direitos e se cumprir deveres em relação às repartições públicas do Estado e, por isso, são acumulados, por imperativos jurídico-administrativos e não por colecionismo). Mais adiante serão elencadas algumas razões compulsórias para a acumulação natural dos conjuntos orgânicos arquivísticos de Pessoa.

Com tudo isso, se reitera que o entendimento da CFP sobre o próprio acervo está em concordância com o termo "espólio", influenciado também por fontes oficias portuguesas. Uma dessas fontes é responsável por matérias legislativas, e no que concerne aos arquivos de Pessoa(s), o Decreto-Lei n 21 /2009 os designa como espólio e os classifica como bem de interesse público, delimitando assim a sua compreensão:

1 - É classificado como bem de interesse nacional o espólio de Fernando Pessoa, compreendido como a universalidade de facto composta por todos os documentos produzidos ou reunidos por Fernando Pessoa, seja na forma de manuscritos autógrafos, isolados ou integrados em documentos de terceiros, assinados ou não, de dactiloscritos ou tiposcritos, com ou sem intervenção autógrafa, assinados ou não, bem como todos os documentos biográficos de Fernando Pessoa ou que registem as suas técnicas e hábitos, assinados ou não, seja qual for o acabamento do texto ou textos neles contidos, e os documentos impressos que se reconheça terem pertencido à sua biblioteca e ostentem marcas autógrafas de utilização. ${ }^{59}$

Cabe ressaltar que o referido marco legal identifica o espólio de Fernando Pessoa como tesouro nacional e que os manuscritos de um modo geral já eram considerados bens culturais em concordância com a Lei do Patrimônio Português (Lei $n^{\circ} 13 / 1985$ ), a qual enquadra esses documentos na sua alínea $c$ do ponto 2 do artigo $8^{\circ}$, de modo não há, ao menos em tese, motivos em vista para excluir os manuscritos pessoanos desta alocação. Entretanto, o termo "manuscritos" / manuscripts abarca documentação de natureza diversa, e isso pode significar que a ideia de manuscrito não seja associada com um arquivo. Já o termo "arquivo manuscrito" representa essa associação e, embora não tenha sido registrado no Dicionário de terminologia arquivística ${ }^{60}$ pelo grupo de trabalho responsável, é possível encontrá-lo na literatura arquivística. Os seguintes autores trabalharam com o conceito de "arquivo manuscrito" / archival manuscript/archivo manuscrito: Hugh Taylor, ${ }^{61}$ Wendy Duff e Kent Haworth, ${ }^{62}$ Terry Cook, ${ }^{63}$ Michael Kurtz, ${ }^{64}$ Walter Brem, ${ }^{65}$ Arlette Farge, ${ }^{66}$ Brian Owens, ${ }^{67}$ Margarita Zas, Francisca Rodríguez e Rosario Rey, ${ }^{68}$ Juan Bolofer ${ }^{69}$ e Tatiana Goryaeva. ${ }^{70}$ Dentre os autores arrolados, Arlette Farge foi a única cuja obra obteve uma tradução para o português brasileiro que preservou o termo "arquivo manuscrito", qualificando-o como um "material vivo". ${ }^{71}$

Se por um lado encontra-se o uso global dos termos "papéis de família" / family papers, "coleções de manuscritos" / manuscript collections, "papéis 
pessoais" / personal papers e "manuscritos privados" / private manuscripts para se referir aos arquivos de pessoas, por outro, o termo "espólio", no caso em tela, é restrito ao território português e, portanto, é uma expressão local para designar os restos dos arquivos de escritores, músicos e autores que foram destacados, reconhecidos, ou são representativos para a sociedade. Essa representatividade pode ser decorrente de um status social a partir de uma linhagem familiar tradicional e/ou nobre, do destaque numa determinada atividade com notoriedade pública ou, ainda, de um legado de bens ou obras dignas de serem preservadas. Entretanto, originalmente o termo "espólio" denomina aquilo que será dividido (por exemplo, divisão entre os herdeiros de um patrimônio) ou ainda aquilo que é objeto da partilha, a ser repartido conforme os interesses na arena das disputas. O termo "espólio" não deixa de ser também o resultado do saque ou de referir-se a pilhagem, sendo possível, ao menos neste sentido, estabelecer uma correspondência com o termo em língua inglesa "spoil". De uma maneira geral essa expressão oculta ou encobre os verdadeiros objetos a que se refere; no caso da CFP, os arquivos de Pessoa(s).

É notável que ainda em 2005 as normas portuguesas definam "espólio" com conceitos arcaicos como "papéis pessoais" / private papers, que por sua vez remontam ao século XIX, quando nem sequer era reconhecido um valor histórico e cultural para os arquivos pessoais - tal como existe amplamente hoje. Por outro lado, no mundo anglófono, o termo "archival manuscripts"72 constitui um avanço terminológico, porque ao menos já se reconhece a natureza arquivística desses documentos.

A adoção do entendimento de fundo de arquivo aos manuscritos pessoanos é capital também porque Pessoa é tão plural quanto seus arquivos, e a estreiteza da noção de espólio não permite integrar os outros eus do autor como criações interligadas aos mais diversos contextos, e não apenas como meras variantes temáticas ou de conteúdo, como aponta o antifuncional "Quadro Classificativo [...] de espólios literários, orientador da distribuição dos documentos pelo inventário, que os organiza em [...] I. Manuscrito do autor: 1.Poesia; 2. Prosa. 3.Teatro; 4.Música (Partituras); 5.Desenhos; 6.Adaptações; 7.Traduções; 8.Edições; 9. Vária"73:

Como entender integralmente o texto "Ultimatum", publicado em Portugal Futurista (1917), sem considerar o contexto da Europa naquele tempo? A abordagem dos espólios se assemelha à das coleções temáticas, que agrupa os documentos sem contextualizá-los, identificando seus tipos, espécies e qualidades sem respeitar princípios arquivísticos.

A ideia do arquivo como espólio também está associada à arca do espólio, que é definida nos seguintes termos:
72. Cf. Duff; Haworth (1990).

73. Lopes (2007, p. 54). 
74. Martins (2010, p. 55).

75. Lopes (2007, p. 52)

76. Cf. Lubar (1999).
A penúltima fotografia incluída no livro de Maria José de Lancastre, "Fernando Pessoa. Uma fotobiografia." (Lisboa, IN-CM 1981), ostenta a legenda "A Arca dos Inéditos". Vê-se na imagem a arca, com a tampa aberta cheia de envelopes e tendo por pano de fundo uma estante preenchida de livros. É a última imagem autêntica da linha biográfica do volume, já que a fotografia derradeira em absoluto é a reprodução de um óleo de Costa Pinheiro. [...] De acordo com a memória de Maria Aliete Galhóz, que teve oportunidade de estudar esse espólio antes de a Biblioteca Nacional o ter acolhido, a arca albergava, "primitivamente sacos de papel e embrulhos atados com cordéis, contendo-se os escritos num primeiro delineamento de classificação e tendo escrito por fora de seu punho [i. e., de Pessoa], o teor dos conteúdos às vezes titulado outras vezes não." (Galhóz, 1993:216). Por outro testemunho, que procura apesentar um objeto complexo no momento que se inicia a inventariação do espólio pessoano, depreende-se que a palavra "arca" se pode referir a três recipientes diferenciados do espólio do autor: 1 .uma arca de grande dimensão, contendo 91 envelopes numerados; 2.uma mala pequena onde se encontravam 25 pacotes (22 numerados e sendo os outros três um saco de plástico, uma pasta de cartão e um embrulhol; 3.25 envelopes numerados, guardados num armário. ${ }^{74}$

$\bigcirc$ verbete dedicado à arca menciona papel, sacos, espólio - citado três vezes no verbete -, cordéis, embrulhos, pasta, envelopes, pacotes, mala e recipiente. † termo "arquivo" não é mencionado, apesar de estar implícito no termo "papel" / paper. Contudo, a Gestão do ACPC da BNP, que é a repartição responsável pela custódia da maior parte do chamado "Espólio Pessoano" registrou em uma obra dedicada aos 25 anos de serviços prestados aos espólios: "Construção das letras, porque é de espólios de escritores que falamos e aí se espera encontrar uma ou mais versões das suas obras literárias e testemunhos do seu processo de criação. Mas um arquivo deste tipo é na realidade bem mais complexo" ${ }^{75}$

Ora, nessa sentença há o reconhecimento explícito de que espólio é um tipo de arquivo, mas que na verdade se trata de um termo que está a ser usado para encobrir ou fazer uma referência, sob o manto de uma palavra considerada mais palatável, ao termo "arquivo". Ao eclipsar o entendimento direto dos arquivos de Pessoa(s), também se eclipsa a percepção da relevância dos arquivos para a sociedade e, principalmente, se desvaloriza a materialidade da literatura e a possibilidade de resgatar o sentido original dos documentos.

Embora isso ocorra, vale registrar que os arquivos possuem o mesmo aspecto de objetos da cultura material, não apenas fisicamente, mas no que tange a significado também, pois para entender um objeto, assim como um arquivo, é preciso considerar a rede de inter-relacionamentos com outros artefatos, materiais impressos, pessoas e espaços de produção cultural onde é possível agenciar ideias, significados e memórias. ${ }^{76}$

Não é por coincidência que os arquivos e a arca de inéditos de Pessoa têm sido objeto de disputa no campo das ideias e interpretações, principalmente 
no campo dos estudos pessoanos. Nesse campo encontra-se a descrição da arca a partir dos seguintes atributos: o físico como objeto visível; o psíquico como sobrevivência de ideias; e o espiritual como depósito de arcanos e segredos de uma tradição cabalística. ${ }^{77}$ Essa abordagem não contribui para a discussão sobre a natureza objetiva e o uso pragmático do objeto, mas reforça a mistificação fetichista sobre o artefato. Por isso, é preciso considerar o entendimento literal sobre esse objeto real e o seu uso instrumental como um receptáculo para o acondicionamento e armazenamento de um arquivo pessoal, constituído como decorrência das práticas de um sujeito que não era apenas escritor, mas também estava inserido num contexto histórico-social.

Há documentos no dito "espólio pessoano" alocados na categoria dos arquivos, dentre os quais estão 45 mil imagens, 27.543 documentos e 343 envelopes. ${ }^{78}$ Consideram-se arquivos manuscritos pessoanos a soma dos autógrafos, dos mistos, dos cadernos e de todos os documentos cuja superfície tenha a marca da grafia de Pessoa. Muitos desses papéis estavam arquivados numa arca descrita da seguinte maneira:

A arca, um caixote de madeira castanho-vermelha com fechadura discreta e pés delicados, vendida em leilão (em 13/1 1/2008) por herdeiros de Teca, durante décadas serviu de adorno à sala de visita da casa da família. [...] Papéis usa de muitas cores: azul claro, branco, cor-de-rosa, sépia. Em parte manuscritos e em parte datilografados (em fitas azuis, pretas, roxas, verdes e vermelhas). [...] usa pedaços de jornais, faturas comerciais, papel timbrado de firmas que trabalha ou "de cópia", folhas de calendário, costas de envelopes já utilizados, "o verso de uma carta", espaços em branco de outros textos, por vezes sem assinatura ou incompletos; e apaga o excesso de tinta com um "mata-borrão branco sujo" que fica "por sobre a grande idade da secretária inclinada". Esse móvel, pequeno e simples, na Rua Coelho da Rocha, ficava à direita da porta do quarto - segundo me confirmou Antônio Manassés, que lá ia quase diariamente nos seus últimos anos, e está hoje na Casa Fernando Pessoa.79

Quanto ao contexto de vida do autor em relação aos seus arquivos pessoais, Fernando Pessoa deixa bastante claro, no documento intitulado "Plano de vida", que possui a intenção de mudar de residência para uma casa ou habitação com mais espaço para o arranjo da sua documentação: "[...] arrumar todos os meus papéis e livros na devida ordem, substituir a minha caixa grande [a arca] por caixas pequenas". ${ }^{80}$ Em uma carta datada um mês antes de seu falecimento, precisamente em 10 de outubro de 1935, o escritor português explicita as condições de organização dos seus arquivos: "Posso dizer-te que já terminei a arrumação preliminar de cerca de três quintos de todos os numerosos loh, quão numerosos) papéis; assim sendo, não falta muito para acabar" ${ }^{81}$

Consequentemente, Fernando Pessoa produziu e acumulou seus documentos em decorrência de práticas culturais cotidianas como a escrita, a leitura silenciosa
77. Cf. Mota (1990).

78. Cf. Cavalcanti Filho (2012).

79. Cavalcanti Filho (2012, p. 108-110).

80. Cavalcanti Filho (2012, p. 110).

81. Cavalcanti Filho (2012, p. 110). 
82. Oliveira (2012, p. 16).

83. Oliveira (2012, p. 16). individual das próprias anotações, a reescrita de poesias, a releitura de seus rascunhos teóricos e principalmente o arquivamento de seus manuscritos para uso futuro nessas mesmas atividades. É cabível salientar que o levantamento de todas as atividades de Pessoa é imperioso para o tratamento documental, pois os tipos documentais são determinados com base funcional na espécie, na ação e no objeto desta ação. Igualmente indispensável é o histórico da cadeia de custódia desses documentos, sobretudo a partir do momento em que o arquivo pessoal se tornou um fundo fechado. Além disso, os contextos de produção, uso, recepção, acumulação e emissão de documentos também são relevantes para as práticas de descrição com vistas a representar os documentos de maneira precisa. Essa acepção encontra fundamento no saber da ciência dos arquivos, ou archival science, pois "a descrição arquivística é uma representação produzida pelo arquivista, decorrente de um processo de pesquisa, com metodologia e métodos próprios da arquivologia, que objetiva a produção de conhecimento sobre os arquivos e o acesso". 82

É certo que a arca faz parte da história custodial que, por sua vez, é um ponto relevante dentre outros que podem ser abordados na descrição arquivística, porém a arca não era o único recipiente de guarda e organização dos arquivos de Pessoa(s). O conjunto extrapola o objeto da arca de modo que documentos foram encontrados em uma mala, em sacos de papel, em embrulhos e pacotes. No caso do subconjunto dos arquivos manuscritos, Pessoa foi produtor desses documentos. Contudo, Pessoa também recebeu e acumulou muitos documentos, como correspondências íntimas e documentos oficiais de diferentes tipos nos quais também fez anotações. Entender a complexidade de materiais e contextos é parte do tratamento documental, pois a descrição depende do "conhecimento sobre quem foi o produtor do arquivo e seus papéis na sociedade, [...] suas funções sociais, até o consequente entendimento do enredamento entre os registros que produziv e acumulou". 83

Objetivando apresentar uma alternativa arquivisticamente embasada ao entendimento de espólio, apontam-se a seguir algumas das razões funcionais compulsórias para a acumulação e sedimentação documentária dos registros pessoais inter-relacionados: (1) instrumentalizar as próprias ações: seja nos tempos presentes da vida de Pessoa ou dos futuros que o autor vislumbrava a partir desses tempos presentes - incontornáveis para as práticas cotidianas na esfera íntima ou social, os arquivos são recursos fundamentais para tomar decisões e dar continuidade aos trabalhos e projetos nos diversos domínios da vida de Pessoa (por exemplo: domínio comercial, comunicativo, social, financeiro, cívico, político, religioso e administrativo); (2) instrumentalizar as ações no domínio literário: na função de escritor, os arquivos serviam para Pessoa como base material pelo menos 
para as seguintes atividades: combinar e recombinar extratos de textos, recorrer aos documentos como fontes de inspiração artística, servir como referência para criação de novas teorias, consolidar os escritos e compor um material para experimentação da escrita sobre variadas temáticas abordadas por meio de diversas formas, gêneros e estilos - no caso de Pessoa, fica patente que não é possível dissociar os materiais utilizados no domínio literário de outros suportes (por exemplo, há manuscritos encontrados no verso de formulários de firmas que no inventário estão sem datação, mas cujas datas podem ser aferidas por meio de análise dos documentos; (3) cumprir com as obrigações: o valor probatório e o valor contábil dos arquivos permitiam que Pessoa cumprisse com seus deveres legais e prestasse contas sobre suas atividades; (4) fazer valer os direitos: era com base nos arquivos como provas que Pessoa poderia reivindicar ou usufruir de seus direitos como cidadão e também como autor; (5) preservar as fontes para uso a posteriori: os documentos que foram preservados e protegidos por ele próprio possuem vários usos potenciais, como investigar, inspirar, emocionar e executar outras práticas que não foram previstas inicialmente. Se Pessoa não tivesse preservado seus arquivos, não teria compreensão da própria obra e, consequentemente, não conseguiria avançar em projetos literários.

A arca de Pessoa era o repositório desses arquivos e não encerrava a totalidade de seus documentos, mas possuía a natureza funcional de um instrumento de experimentação no contexto de um laboratório de produção de escrita. A ordem original dos arquivos da arca também tinha um aspecto editorial, uma vez que:

Não se trata afinal de papéis avulsos, sem princípio de ordem, e a ordenação arquivística do autor aproxima-os de uma ideia de reunião que caracteriza os volumes. [...] Pessoa legou-nos uma obra principalmente contida num arquivo, cujo suporte, o papel, como na imagem da arca, remete para outra realidade, a do livro. [...] A própria revisão do texto em Pessoa, que em nenhum caso o poeta considerou estar concluída, apela à necessidade de pensar conjuntamente os planos estético e editorial. Como escreve a propósito do Livro do Desassossego, este exigiria, no final dos anos 20, uma nova "organização", baseada "numa escolha, rígida quanto possível, dos trechos variadamente existentes", adaptando-os à "vera psychologia" de Bernardo Soares. ${ }^{84}$

A ordenação de Pessoa corresponde na teoria arquivística tradicional à ordem original do produtor. Isto posto, é preciso considerar que Pessoa tenha organizado os conjuntos documentais segundo sua própria lógica. Dentre os documentos do que constitui seu arquivo, sabe-se que há um significativo número de correspondências que atualmente encontram-se dispersas nas coleções. No contexto de sua função profissional, Fernando Pessoa defendeu as boas práticas de organização dessa espécie documental da seguinte maneira: 
A organização dos arquivos [... ] é um dos pontos mais importantes da organização interna de qualquer escritório, seja industrial ou comercial. [...] $\bigcirc$ arquivo de correspondência divide-se, pois, em duas partes - a que deve ser disposta e organizada para fácil consulta imediata; e a que deve estar convenientemente arrumada para consulta pouco morosa em qualquer ocasião. Já tratámos da disposição da correspondência recente, quando estudámos - foi o segundo problema nesta matéria - o "processo material de arquivo". Resta agora que tratemos do arquivo permanente da correspondência e das suas relações com o arquivo corrente. A grande maioria das casas estabelece o arquivo permanente da correspondência por classificação cronológica [...] A nosso ver - e nisto somos coerentes com tudo quanto aqui temos exposto: o arquivo permanente de correspondência deve obedecer a princípios idênticos aos do arquivo corrente. ${ }^{85}$

A acumulação dos arquivos de Pessoa(s) não difere dos outros conjuntos de arquivos, que incluem não só papéis, mas também outros suportes, formas, tipos, formatos e gêneros de documentos. Entende-se essa constituição natural dos documentos de arquivo a partir da perspectiva da teoria dos arquivos totais, o que em termos práticos sinaliza que os arquivos, os livros que constituem a biblioteca privada e os artefatos pessoais que usualmente encontram-se em museus são um todo orgânico intelectualmente indissociável.

Os elementos desse arquivo total são como as antigas tésseras que refletem os modos de vida do indivíduo inscritos em sua relação íntima consigo e com a sociedade, fazendo sentido somente quando contextualizados. Desse modo, os arquivos manuscritos têm uma relação direta com as práticas de Pessoa. Nesse enfoque as superfícies dos documentos são espaços e lugares de experiências artísticas em um ambiente de experimentos, análises, avaliações, seleções, produções, combinações e recombinações. Essas operações incluem as notas nos livros que fazem parte dos arquivos totais de Pessoa, mas estão fragmentados na Biblioteca Pessoal da CFP. Consequentemente, os arquivos de Pessoa(s) incluem livros, contratos, marginálias, registros, selos, autógrafos, diários pessoais, documentos epistolares, cartas astrais, estudos, cartas de amor e outros objetos de uso particular, que refletem a vida do produtor/acumulador. É peremptório frisar que as marginálias da Biblioteca Particular da CFP são também manuscritos intelectualmente indissociáveis das outras partes do fundo fechado de Pessoa.

Ao refletir-se sobre a ordem original da documentação pessoana e os fragmentos encontrados nos espólios da CFP e da BNP, contata-se que ocorreu uma violação do princípio da ordem original, que acarretou o desmantelamento dos vínculos entre os documentos, o extravio de peças documentais (por exemplo, os livros desaparecidos) e a perda do sentido original do arquivo enquanto conjunto. Ao observarem-se os inventários e as organizações dos espólios, não se encontram séries 
documentais tipológicas ou classificação arquivística, mas agrupamentos temáticos como "Política", "Religião", "Ocultismo", que mantêm as peças funcionalmente apartadas. Nota-se que as intervenções no acervo não observaram o princípio de respeito aos fundos, a classificação arquivística ou uma serialização tipológica, portanto não preservaram a sequência funcional decorrente das atividades de Pessoa.

A perspectiva da manutenção do termo "espólio" não impede que esse modelo possa ampliar-se para uma abordagem multidisciplinar que inclua diversas contribuições, como as práticas de descrição arquivística e o reconhecimento de que se trata de um fundo fechado de arquivo. Isso significaria minimamente a identificação das espécies, dos gêneros, dos formatos e dos tipos documentais; a apuração das formas ou da tradição documental; o levantamento das datas tópicas e crônicas; a reconstituição da história custodial; o mapeamento dos eventos ou ocorrências associadas à produção e uso dos arquivos; a inserção de descritores/ metadados para preservação da autenticidade dos originais; a recuperação dos contextos de criação, utilização e acumulação; a leitura de manuscritos com grafias difíceis através da paleografia contemporânea; e a preservação das relações orgânicas dos subconjuntos documentais.

Se o entendimento de espólio fosse ajustado ou revogado tendo em vista o integral tratamento dos fundos custodiados com a aplicação dos princípios da arquivística, isso também impactaria nos outputs, principalmente na web de outros campos do saber que podem ser relacionados a acervo, como as humanidades digitais, a filologia, as ciências da informação, a arquitetura da informação, a ontologia informática, a diplomática e a crítica genética. Observando as boas práticas da arquivística, poder-se-ia reconstituir pelo método dedutivo os arquivos de Pessoa(s), tal como um paleontólogo descobre a ossatura de um animal extinto, redefine sua anatomia original e organiza o esqueleto. Em termos práticos, esta organização lógica corresponde a um plano de classificação do fundo fechado. Este, por sua vez, pode ser definido como "um conjunto de arquivos ao qual não se irão juntar mais documentos, como é o caso, por razões evidentes, do arquivo de uma pessoa falecida". ${ }^{86}$ Entretanto, o que poderia ser um fundo fechado foi convertido em espólios fragmentados e dispersos ao menos nos sete núcleos de custódia a seguir: (1) a coleção de José Paulo Cavalcanti Filho, no Brasil; (2) a parte ainda restante da herança da instituição familiar de Manuela Nogueira, em Portugal; (3) a coleção Gerald Yorke do Instituto Warburg da Escola de Estudos Avançados da Universidade de Londres; (4) a parte restante da herança da instituição familiar de Miguel Rosa, em Portugal; (5) o dito "espólio" do ACPC da BNP; (6) a coleção da Universidade Brown, nos Estados Unidos; e (7) o acervo da Casa Fernando Pessoa, em Lisboa.
86. Rousseau; Couture (1998, p. 92). 
87. O conceito de difusão adotado corresponde à seguinte definição: processo cujo objeto é a informação emitida com o objetivo último da acessibilidade via produtos e serviços, tais como publicação de instrumentos de pesquisa on-line, curadoria digital de acervos, homepage institucional e webdifusão nas redes sociais.

88. Lopes (2007, p. 53-68)
Dentre todos os núcleos é o ACPC da BNP que concentra a maior parte dos fundos fechados de Fernando Pessoa. Em concordância com esta responsabilidade, por razões óbvias de preservação do material, o ACPC restringe o acesso aos arquivos manuscritos de Pessoa. A BNP, por meio da seção de coleções especiais, faculta aquisição das cópias dos arquivos digitalizados sem que, no entanto, as peças documentais no formato digitalizado tragam consigo os metadados da descrição arquivística. Essas cópias dos arquivos digitalizados totalizam 64.017 itens alocados em 760 pastas ocupando 78,8 GB de memória de disco rígido. Cabe evidenciar que tais itens digitalizados correspondem não apenas aos inéditos e manuscritos pessoanos, mas também abrange todo e qualquer documento incorporado ao Espólio Fernando Pessoa inventariado parcialmente na Base de Dados de Espólio Literários.

Nota-se que para ter acesso a essa documentação é preciso ter condições econômicas para tanto, pois é necessário adquirir um HD externo e efetivar uma requisição sujeita a retirada in loco na BNP, Cidade Universitária de Lisboa, e, depois, estar em pleno acordo com a assinatura de um termo adequado sobre os direitos de uso dos arquivos eletrônicos. Também é preciso dispor de conhecimento avançado e tempo para ler item por item, uma tarefa desafiadora mesmo para os investigadores acadêmicos e, portanto, incompatível com a realidade da maioria da população portuguesa. Urge salientar que do ponto de vista técnico não há impedimentos para que a BNP realize a descrição, a difusão ${ }^{87}$ e a mediação cultural desses documentos.

Uma vez que o acesso aos arquivos manuscritos de Pessoa é econômica e intelectualmente elitista, pois está condicionado apenas àqueles que possuem capital econômico e intelectual para receber mais de 64 mil cópias de arquivos digitalizados a serem analisados um a um, sem descrição, constata-se que a BNP exclui a maioria dos contribuintes, que não dispõem de tempo e recursos para requerer e percorrer milhares de páginas aparentemente ininteligíveis.

Existem pessoas dispostas a cumprir tal tarefa, contudo, esse é o perfil de uma pequena elite intelectual, limitada ao público acadêmico, como registra a gestão dos espólios do ACPC da BNP:

Quando estes arquivos passam para o nosso lado, é certo que, mais cedo ou mais tarde, há um investigador que vai precisar de saber aquilo que, afinal, contém. E não foi para isso que os adquirimos? [...] No percurso que estes "papéis" percorrem entre a casa em quem porventura tomaram forma e o momento em que estão acessíveis à comunidade científica várias mãos interferem. ${ }^{88}$ 
É nesse contexto que ocorre a elitização daquilo que é de domínio público, aquilo que poderia/deveria ser usufruído por todos e que existe para todos. A BNP segue, ao menos neste ponto, na contramão da democracia e da democratização como eixos da mediação cultural, pois não adota proativamente uma dinâmica aproximativa para com a sociedade. Por isso, não condiz com o caráter público da CFP e da BNP ignorar as populações marginalizadas, como os ciganos, as comunidades de baixa renda lem Portugal, sobretudo a população rural, as pessoas idosas pensionistas e populações negras), lésbicas, gays, bissexuais, travestis, transexuais, pessoas com deficiência, pessoas moradoras de rua, comunidades de refugiados e analfabetos por opção cultural ou determinação social.

Isso não é uma questão menor, porque as instituições públicas de custódia deveriam, ao menos em teoria, condizer com os atributos do Estado democrático de direito. Portanto, considera-se que o privilégio de atendimento aos acadêmicos não coaduna com uma instituição democrática.

Tendo em vista que os serviços de uma instituição de custódia de documentos arquivísticos não se esgotam no arquivamento e na abertura de portas, para que apenas uns pouquíssimos privilegiados tenham acesso ao patrimônio público, financiado por todos, é razoável defender o encadeamento entre as funções arquivísticas para que os arquivos manuscritos de Pessoa(s) possam ser levados aos públicos, onde quer que estejam, desde a formação destes até o processamento técnico, a comunicação e a mediação (Quadro 1).

Quadro 1 - Correspondência entre o papel cultural do Arquivo de Cultura Portuguesa Contemporânea e as funções, serviços e processos arquivísticos relativos aos fundos fechados Fernando Pessoa.

\begin{tabular}{|c|c|c|}
\hline Papel cultural & Funções arquivísticas & Serviços e processos \\
\hline $\begin{array}{c}\text { Formação do patrimônio } \\
\text { arquivístico cultural }^{89}\end{array}$ & Aquisição e produção & $\begin{array}{l}\text { Negociação de aquisições; licitações; normatização para doadores de } \\
\text { fundos; inventariamento dos documentos ou fundos doados; controle de } \\
\text { entrada de documentos em fundos por via extraordinária; elaboração } \\
\text { dos termos de aquisição ou doação; modelagem e padronização da } \\
\text { redação dos documentos orientadas pelos tipos documentais; definição } \\
\text { de hierarquia dos documentos; controle da linguagem dos registros; } \\
\text { elaboração de manuais para a produção de documentos administra- } \\
\text { tivos e técnicos; elaboração e implantação do programa de gestão } \\
\text { da produção documental; estudos de tipologia documental e gênese } \\
\text { documental; identificação dos documentos constitutivos, de reunião, de } \\
\text { direção, de recursos humanos, de comunicação, da área contábil e } \\
\text { financeira, do setor jurídico e da atividade-fim; gerenciamento da estru- } \\
\text { tura dos arquivos natodigitais através do Office Open XML. }\end{array}$ \\
\hline
\end{tabular}

89. Ver Luiz Antonio Santana da Silva e Telma Campanha de Carvalho Madio (2012). 


\begin{tabular}{|c|c|c|}
\hline Papel cultural & Funções arquivísticas & Serviços e processos \\
\hline $\begin{array}{l}\text { Processamento } \\
\text { técnico do patrimônio } \\
\text { arquivístico cultural }\end{array}$ & $\begin{array}{l}\text { Arranjo, descrição e } \\
\text { gestão documental }\end{array}$ & $\begin{array}{l}\text { Serialização; organização do acervo; arquivamento; ordenação; mapea- } \\
\text { mento topográfico; elaboração do quadro de arranjo; identificação dos } \\
\text { fundos de arquivo; logística informacional e da armazenagem; acondicio- } \\
\text { namento, armazenamento e recebimento de caixas armazenadas; emprés- } \\
\text { timos de dossiês; transporte de documentos; controle dos documentos para } \\
\text { transferência ao arquivo intermediário e recolhimento ao arquivo permanente; } \\
\text { identificação dos conjuntos documentais, funções, subfunções e atividades; } \\
\text { identificação dos tipos documentais; codificação; elaboração do plano de } \\
\text { classificação; aplicação de normas de descrição; elaboração de instrumen- } \\
\text { tos de pesquisa; descrição via ICA-AtoM (software livre para descrição arqui- } \\
\text { vístical;; GDE - gestão de documentos eletrônicos (digitalizados ou natodigi- } \\
\text { tais); GED - gestão de documentos eletrônica (por meio de software). }\end{array}$ \\
\hline $\begin{array}{c}\text { Comunicação do } \\
\text { patrimônio arquivístico } \\
\text { cultural }\end{array}$ & Difusão & $\begin{array}{l}\text { Digitalização; curadoria digital; elaboração de Instrumentos de pesquisa } \\
\text { on-line e search engines; difusão de informações via webpage instituci- } \\
\text { nal; acessibilização de informações arquivísticas por meio de bancos de } \\
\text { dados; serviços reprográficos; açães comunicativas, de marketing e de } \\
\text { promoção institucional; estudos de usuários; difusão via softwares livres } \\
\text { (ICA-AtoM, Archon, Sepiades); difusão via web } 2.0 \text { (blogs, sites, wikis, } \\
\text { folksonomia, }, 0 \text { tags, mashup, RSS, Google Docs, Flickr, Last.fm), difusão } \\
\text { via web 3.O (conteúdos sem navegador, inteligência artificial, web semân- } \\
\text { tica, web 3Dl; modelagem, implantação e gestão de plataformas digitis } \\
\text { colaborativas; produção de sites utilizando markup languages como XML- } \\
\text { Term, RDF Inference Language, TEl (text-encoding initiative), EAD (encoded } \\
\text { archival description), ECD (encoded context description), MARCXML, MEl } \\
\text { (music-encoding initiative), MODS (metadata object description schema), } \\
\text { Dublin Core XML; criação de nuvens de tags; produção de webpages } \\
\text { com edições on-line de manuscritos. }\end{array}$ \\
\hline $\begin{array}{c}\text { Mediação do patrimônio } \\
\text { arquivístico cultural }\end{array}$ & Mediação & $\begin{array}{l}\text { Concepção, implantação e gerenciamento de uma programação cultu- } \\
\text { ral ofertada aos diversos públicos; realização de práticas de mediação } \\
\text { cultural; planejamento, execução e controle de projetos culturais; presta- } \\
\text { ção de serviços educativos e de produção cultural; criação, implantação } \\
\text { e coordenação de programas de educação patrimonial em parcerias } \\
\text { com instituições de ensino; captação de recursos por meio de parcerias } \\
\text { e editais do setor da cultura; criação, implantação e coordenação do } \\
\text { serviço de referência; estudos de públicos; concepção, implantação e } \\
\text { gerenciamento de um plano de ações de valorização e exploração dos } \\
\text { documentos e do espaço institucional; criação de dispositivos interativos } \\
\text { de mediação da informação; atualização das representações dos arqui- } \\
\text { vos nos instrumentos de pesquisa de acordo com as necessidades do } \\
\text { acesso; criação de linhas de produtos culturais e informacionais. }\end{array}$ \\
\hline
\end{tabular}




\begin{tabular}{|c|c|c|}
\hline Papel cultural & Funções arquivísticas & Serviços e processos \\
\hline $\begin{array}{c}\text { Preservação do } \\
\text { patrimônio arquivístico } \\
\text { cultural }\end{array}$ & $\begin{array}{l}\text { Preservação, conser- } \\
\text { vação, restauração }\end{array}$ & $\begin{array}{l}\text { Higienização; armazenamento; acondicionamento; diagnóstico; } \\
\text { desinfestação; tratamentos mecânicos e/ou químicos; controle do } \\
\text { ambiente, do transporte, do manuseio e da exposição dos docu- } \\
\text { mentos; intervenções mecânicas, estruturais, estéticas e/ou químicas } \\
\text { de restauro; migração e emulação de documentos eletrônicos com } \\
\text { softwares e/ou hardwares obsoletos; preservação da autenticidade } \\
\text { e integridade dos documentos digitais via softwares (Archivematica, } \\
\text { ArchivesSpacel; manutenção da integridade da cadeia de custódia } \\
\text { para preservar provas/arquivos em meio digital no sistema informa- } \\
\text { tizado de gestão arquivística de documentos e nos repositórios ar- } \\
\text { quivísticos digitais confiáveis. }\end{array}$ \\
\hline
\end{tabular}

Fonte: Adaptação do autor com base em Aldabalde (2015).

encandeamento dessas funções arquivísticas é relevante, porque o dito "espólio pessoano" da BNP influencia o entendimento da CFP sobre o seu próprio acervo. $O$ espólio é resultado de um arranjo que não observa o princípio da integridade $^{91}$ dos arquivos de Pessoa(s), permitindo a adição indevida de documentos e o recolhimento do fundo mutilado, disperso e alienado. Isso porque o entendimento dos arquivos como espólio resulta na inobservância do princípio da proveniência, o que impacta na preservação da integridade que derivaria do respeito aos fundos. Num entendimento sob o viés do espólio é permitido haver mesclas entre arquivos pessoanos e documentos produzidos por terceiros /por exemplo, pesquisadores). Aplicado metodologicamente, o respeito à proveniência poderia evitar a confusão entre documentos de produtores diferentes no mesmo conjunto. Arquivisticamente tratados, os documentos de estranhos não estariam no chamado "espólio" nem embutidos nas cópias digitalizadas fornecidas pela BNP.

Além de adições indevidas, o entendimento de espólio dá margem para fragilidades no controle descritivo dos documentos e, portanto, também pode ocorrer que documentos do produtor que oficialmente deveriam constar no dito "espólio" não estejam nele. Esse é o caso de algumas peças documentais relativas ao Dossiê Crowley-Pessoa, reunido com o objetivo de agrupar todos os registros que se inscrevem no âmbito da relação estabelecida entre Fernando Pessoa e Aleister Crowley (1875-1947). Mas antes de tratar da dispersão do acervo no caso deste dossiê é cabível indagar: quem foi Crowley?

Aleister Crowley é descrito como herdeiro rico em Londres, mago inglês, homem mundano, alpinista nas montanhas mais altas de Caracórum, espião para a British Intelligence em Nova lorque, estudante em Cambridge, ocultista, boêmio em Paris, iogue no antigo Ceilão, praticante de magias sexuais, profeta de uma
90. Taxonomia espontânea feita pela colaboração dos usuários.

91. Bellotto (2002, p. 21). 
92. Cf. Dix (2009).

93. Dix (2009, p. 46-47).

94. Cf. Dix (2009).

95. Dix (2009, p 39).

96. Cf. Espólio (2008).

97. Cf. Les Documents (2016).

98. Cf. McLaughlin (2012).

99.Cf. Le Contrat (2014). religião própria na Sicília, pintor em Berlim, personagem extrovertida, poeta, escritor de poemas satíricos contra Mussolini intitulados Songs for Italy, excelente jogador de xadrez, membro de ordens secretas, viajante incansável, personalidade célebre e marginal, ao mesmo tempo que manteve relações estreitas com Auguste Rodin, Aldous Huxley e outras personagens históricas das artes no mundo. ${ }^{92}$

Sobre a incompatibilidade entre Pessoa e Crowley diz Steffen Dix: "Se juntarmos a esta vida agitada a sua extensa e intensa atividade bissexual, o consumo de drogas e a permanente convivência com várias mulheres, temos que concluir que quase não pode haver personalidades mais diferentes". ${ }^{93}$ Há documentos que evidenciam que Crowley teve o intuito de estabelecer suas ordens em Portugal através de Pessoa e, segundo o escritor contemporâneo Raul Leal, que a ambos conhecia, Crowley chegou a ser visto como culpado pela morte de Pessoa. ${ }^{94}$ Os documentos do Dossiê Crowley-Pessoa são relevantes porque são imprescindíveis para compreender determinadas peças da produção literária de Pessoa, dentre as quais uma novela policial baseada no encontro com Crowley no dia 2 de setembro de 1930 em Lisboa. Apesar de o Instituto Warburg da Universidade de Londres custodiar arquivos referentes à relação entre os dois autores, é notável que "nenhum dos documentos que se referem à correspondência entre Pessoa e Crowley ou aos fragmentos com o título The Mouth of Hell está catalogado no espólio oficial da Biblioteca Nacional. Encontram-se ainda na posse na família do poeta". 95

Ao levar-se em consideração as posses ou heranças da família de Pessoa e sua venda ao Estado, é preciso recordar que no dia 13 de novembro de 2008 ocorreu um leilão de documentos remanescentes do arquivo de Pessoa com o valor de venda total previsto pela P4 Photography para mais de 400 mil euros, ${ }^{96}$ e dentre os setenta lotes destacou-se o Dossiê Pessoa-Crowley, avaliado em 50 mil euros. Tendo em vista que a BNP comprou o dossiê e que essa soma é investimento no tesouro nacional, o interesse pela metodologia arquivística pode ser visto como política de controle do patrimônio documental de interesse do Estado português. Não se sabe exatamente o valor monetário atribuído a todo o espólio pessoano, entretanto, no mercado de manuscritos, um acervo pode chegar a milhões de euros. As cartas íntimas, fotografias e manuscritos de Marcel Proust foram vendidos por 1,2 milhão de euros. ${ }^{97}$ Os arquivos pessoais de Henry Dundas foram comprados por 1,35 milhão de libras pelo Arquivo Nacional da Escócia. ${ }^{98}$ Um único documento pode ultrapassar 2 milhões de reais, como no caso da licença de casamento de Napoleão e Josefina, vendida por 437.500 euros. ${ }^{99}$ 
Tendo em conta essas questões relativas à gestão e aos valores dos arquivos e o estabelecimento de padrões arquivísticos bem instituídos, não se considera remota a possibilidade de que faltem documentos no "espólio" da BNP, pois há correspondências íntimas e outros documentos que possivelmente estão ainda em posse de herdeiros. Entende-se que seria necessário verificar se os herdeiros transmitiram todos os arquivos referentes ao Dossiê Crowley-Pessoa, pois a BNP não possui instrumental arquivístico para verificar, controlar e auditar os documentos que eram discriminados antes, durante e depois das transações. Também não há notícias de que conste nos registros transacionais a discriminação de um levantamento prévio e póstumo da aquisição. Vale destacar que a aquisição é uma das funções arquivísticas estabelecidas junto às demais, isto é: a produção, a classificação, a avaliação, a descrição, o arranjo, a preservação, a mediação e a difusão.

$\bigcirc$ entendimento dos arquivos de Pessoa(s) como espólio impactou não apenas o processamento arquivístico como também procedimentos técnicos, como a digitalização dos arquivos. Essa foi realizada por pastas codificadas, contrariando o fundamento mais básico da arquivística, de que "os arquivos são extensões das entidades ou pessoas que os acumularam; que por isso mesmo assumem fisionomia própria e exclusiva; e que têm no contexto, e não no conteúdo, o mais importante elemento para sua classificação". ${ }^{100}$

Entender por espólio aquilo que é na verdade arquivo influencia também as responsabilidades dos custodiadores, pois há diminuição dos cuidados em função do entendimento colecionista no qual os documentos não precisam ser necessariamente descritos no sentido de preservar sua autenticidade e controlar a fidedignidade. Essas qualidades são ainda mais frágeis e, portanto, mais dignas de atenção, quando a digitalização não é acompanhada por uma metodologia arquivística.

É notável que a oração "está tudo na internet" tenha sido recorrentemente recitada pelos funcionários da CFP e da BNP. A repetição da frase que pareceu um mantra não se sustenta quando se verifica que apenas quarenta itens estão disponibilizados com tratamento no dito "espólio pessoano", ao menos até a presente data. ${ }^{101}$ Ainda que as cópias digitais estivessem acessíveis via web, isso não poderia - a ponto de comprometer a própria razão de ser da instituição servir de justificativa para o abandono dos arquivos originais ou para a transferência de responsabilidades aos pesquisadores. ${ }^{102}$

Pode-se presumir que, pelo menos em alguma medida, a tendência da digitalização pode vir a ser acompanhada pela sensação de perda da responsabilidade legal pela custódia dos arquivos. Aliada a essa ideia está o
100. Camargo (2012, p. 7).

101. Estudo pós-doutoral ocorrido de 19 de agosto de 2016 até o mês de fevereiro do ano subsequente.

102. É possível apontar que, embora não seja uma obrigação laboral, mas movidos por um voluntarismo, provavelmente nos próximos anos os pesquisadores incluirão os arquivos manuscritos de Pessoa em edições na $\boldsymbol{w} \boldsymbol{e} \boldsymbol{b}$, repositórios digitais ou curadorias on-line. Assim, a colaboração multilateral de pesquisadores pode ter papel central na democratização destes documentos e na reintegração dos fundos pessoanos, ainda que por uma custódia distribuída. 
103. Kent (2002).

104. Cf. McKemmish (2017).

105. Entende-se que a pluralização corresponde ao desprendimento do arquivo de seus fins originais para usufruto de pessoas em contextos plurais, e isso inclui a construção da memória coletiva e as intenções de identidade. Na teoria records continuum a pluralização está ligada a outras três dimensões: (1) a geração a partir do traço da ação ou marca do produtor do arquivo num determinado contexto transacional; (2) a captura ou o registro da atividade que ao ser preservado em sua integridade pode manter o seu valor de evidência e prova; (3) a organização dos arquivos de uma família, indivíduo ou empresa.

106. Lemay (2015).

107. International Council on Archives (1996, p. 1-3). Tradução minha.

108. Shellenberg (2006, p. 359). senso comum de que o suporte digital é substitutivo do original. Neste segmento destaca-se a estratégia da custódia distribuída, ou pós-custódia, ${ }^{103}$ adotada pelos arquivos australianos, sendo admissível no caso em tela, já que os arquivos pessoanos foram divididos em, ao menos, sete núcleos de coleções distintas já enumeradas.

Contudo, a distribuição de custódia e a adoção de estratégias pós-custodiais não significam a redução de responsabilidades dos protetores legais dos documentos. No contexto da teoria records continuum, 104 uma das dimensões de atuação dos custodiadores é a pluralização ${ }^{105}$ para além da memória organizacional ou individual no sentido de atender as necessidades das pessoas e das comunidades marginalizadas. Nesse contexto parte-se da premissa de que o tratamento arquivístico não se esgota no arquivamento e que a exploração faz parte de outra esfera dimensional do universo arquivístico, que parte de pluralizar os arquivos. ${ }^{106}$

Diante da cedência de um pós-custodialismo reducionista é preciso salientar o perigo dos danos irreversíveis ao patrimônio público causados pelas práticas dessas ideias atreladas ao lobby dos arquivos apenas enquanto informações, descuidando da materialidade. Esse tipo de abordagem aplicada aos arquivos de Pessoa(s) poderia significar, na prática, o total descaso com os originais, o que por sua vez implicaria em subestimar o valor probatório, o valor científico e os valores culturais materialmente fixados nesses documentos. E com base em quêe? Somente a partir duma premissa irrazoável de que no ambiente eletrônico é possível cumprir incumbências sem assumir as responsabilidades pela custódia? Observamos duas inconsistências nesse pós-custodialismo reducionista: a primeira é ética e a segunda é técnica. A primeira corresponde a aceitar a substituição do patrimônio documental pela informação digital sem levar em conta o valor insubstituível dos originais, tanto para efeito de prova quanto como fonte privilegiada de pesquisa científica. Isso corresponde ao ferimento da ética arquivística no mínimo nos seguintes pontos:

2. Arquivistas devem avaliar, selecionar e manter o material de arquivo em seu contexto histórico, legal e administrativo, assim observando o princípio da proveniência, preservando e tornando evidentes os vínculos originais dos documentos. [...] 3. Arquivistas devem proteger a autenticidade dos documentos durante o processamento arquivístico, a preservação e o uso. [...] 10. Arquivistas devem promover a preservação e o uso do patrimônio documental mundial, através do trabalho cooperativo com os membros de sua e de outras profissões. ${ }^{107}$

Indo ao encontro desse código de ética, é possível encontrar uma noção geral que embasa esses pontos: "Os arquivistas são, pois, guardiões da verdade ou da prova sobre cuja base pode afirmar-se a verdade". 108 
A segunda inconsistência de um pós-custodialismo reducionista é de ordem técnica, pois mesmo que os arquivos fossem todos digitalizados, migrando para um ambiente eletrônico, ainda assim esses arquivos teriam uma materialidade dependente da manutenção de suportes tecnológicos em que se registram os documentos, do encadeamento da custódia, de cuidados e de tratamento para preservar a integridade, autenticidade e fidedignidade a fim de que os arquivos não sejam adulterados ou corrompidos no decorrer dos usos. Portanto, além da falta de consciência arquivística, essa segunda inconsistência é também um sinal de escassez no conhecimento da natureza dos arquivos digitais e da própria informática. Não é por acaso que a ênfase na informação é considerada antiarquivística, $^{109}$ e isso é válido para um pós-custodialismo reducionista que privilegia a informação virtual em detrimento da real. Assim, teoricamente, aqui se defende a posição de que a questão principal não é a custódia, mas o estabelecimento de políticas e procedimentos que garantam a gestão dos arquivos de acordo com padrões bem estabelecidos. ${ }^{110}$ Sendo assim, mesmo que a CFP não seja a principal instituição custodiadora dos arquivos de Pessoa(s), sua responsabilidade não decresce, pois se houvesse consciência sobre a origem de seus documentos - no que deveria ser um fundo fechado - e a especificidade do material de arquivo fosse levada em conta, então a CFP poderia programar uma política arquivística.

Um desses modelos se encontra no campo da descrição: a Norma Geral Internacional de Descrição Arquivística (ISAD(G)), do Conselho Internacional de Arquivos (CIA). A inobservância da $\operatorname{SAD}(G)$ impacta também na difusão dos arquivos manuscritos pela internet, pois a CFP é capaz de manter a sua plataforma virtual em interoperabilidade com o software ICA-AtoM, e a BNP poderia ter disponibilizado os 28 cadernos anotados através do Open Source Archival Description Software, mas não se encontram descrições que possam representar com integridade os documentos. Os usuários têm de visualizar página por página para alcançar aquilo que buscam. Os formatos de dados são densos e um equipamento rápido é necessário, porque o tamanho do documento digitalizado possui alta densidade de resolução e o seu processamento tende a ser moroso.

Entender os arquivos de Pessoa(s) como espólio também influencia a difusão do material, inclusive sua difusão científica. A utilização dos documentos pelos pesquisadores é recorrente, mas as referências não são precisas quanto ao procedimento metodológico adequado para remeter à documentação arquivística. Por um lado se faz a seguinte referência: "Existe, no espólio, um texto de crítica a Orpheu l, seguramente saído da pena de Pessoa fingindo ser um jornalista português 
111. Lopes (2016, p. 420).

112. Sá-Carneiro (2015, p. 281, p. 594).

113. Lemay (2015, p. 297).
[...] Espólio pessoano na B.N. 87-43 e 44". 111 Por outro, na seção "Cartas de Fernando Pessoa" consta uma carta assinada por Mario de Sá-Carneiro com os seguintes apontamentos:

12 Set[embro] 1914 Meu Querido Amigo Portanto como hoje você não apareceu - na segunda-feira espero-o no mesmo local. Por oura espere-me você até às 6 horas; se até ai eu não aparecer você pode-se ir embora. Mas espere-me até as 6 horas. $\bigcirc$ seu Mário de Sá-Carneiro. [...] No arquivo de Pessoa conserva-se apenas uma cópia dactilografada desta carta. [...] 98.1 15. Anexo - 148r. O original deste postal não se encontra no arquivo. ${ }^{112}$

Observa-se então que uns mantêm o termo "espólio" fazendo referência a BNP ao passo que outros remetem ao "arquivo de Pessoa". Isso evidencia que há um impacto desse entendimento para os mediadores do conhecimento e para a exploração do valor acadêmico, mas quiçá também de outros valores. E nesse sentido é preciso levar em conta que a CFP, enquanto espaço de mediação cultural, não se reduz apenas a um espaço dedicado à comunidade acadêmica, mas está a atuar com diversos valores na direção do conceito da exploração: identidade, emoção, dialética, materialidade e capacidade do arquivo em produzir um efeito. ${ }^{113}$

Tendo em vista que a representação arquivística é potencialmente a matriz de todas as outras representações decorrentes da exploração de valores dos bens culturais, uma intervenção arquivística poderia recuperar o sentido original dos arquivos, ainda que a separação física das peças documentais fosse irreversível, contribuindo assim para uma exploração, uma difusão e uma mediação cultural que valorizassem as ligações entre os documentos numa lógica conjuntural. Por exemplo: um plano de classificação poderia vir a ser uma fonte para representações artísticas que buscassem valorizar a estética da conectividade entre os documentos. Por conseguinte, a ausência de representações arquivísticas impacta, ao menos potencialmente, nos sentidos das demais representações dos arquivos manuscritos de Pessoa, inclusive das representações que serão objetos da próxima seção.

Considerando tudo o que foi apontado, constata-se que o entendimento dos arquivos de Pessoa(s) como espólio levou a faltas no tratamento documental, o que na prática é uma forma de confisco e de ocultamento da documentação. Entretanto, a mediação cultural pode vir a ser um processo de luta contra esses óbices através das estratégias de democratização e democracia cultural. Ora, se o tratamento da maior parte do espólio ficou a cabo do ACPC da BNP, que como foi exposto apresenta um perfil institucional incompatível com um arquivo e com uma instituição proativa em relação à democratização cultural, logo o papel da CFP centra-se em mediar o legado de Fernando Pessoa, e com isso torna-se possível democratizar o patrimônio documental. 
Objetivando conhecer de que forma os arquivos manuscritos ocultados têm chegado ao público buscou-se inferir o peso dessas representações e identificar as práticas como espaços onde essas representações estiveram presentes. A seguir apresentam-se os resultados quantitativos e qualitativos.

\section{AS REPRESENTAÇÕES DOS ARQUIVOS MANUSCRITOS NA CASA FERNANDO PESSOA}

Na fachada do edifício da CFP é possível observar a representação de um dos arquivos manuscrito de Pessoa em grandes letras cursivas, a simular a grafia do poeta: "Se a ciência é vida, sábio é só o néscio". O arquivo original representado possui doze versos datados de 20 de fevereiro de 1928, sob o heterônimo de Ricardo Reis. Essa única peça documental deu origem ao projeto Casa-Poema, que permeia a superfície da CFP. Adentrando a casa, logo após o átrio, no chão, há outra representação de um manuscrito de Pessoa: um mapa astral. É possível observar diretamente representações dos arquivos manuscritos pessoanos expostas na CFP durante em um percurso por, pelo menos, dez ambientes diferentes e integrados.

No primeiro andar da CFP há uma loja onde se comercializam produtos institucionais e uma prateleira reservada às edições produzidas pela própria casamuseu, que se encontram, em sua maioria, disponíveis para aquisição pelo valor democrático de um euro. Também há produtos de origem externa, sobretudo livros, e produtos fonográficos, audiovisuais, objetos de decoração, materiais de escritório, material escolar, acessórios, roupas, utensílios e artesanato. Todos os produtos se centram na figura histórica de Pessoa; no entanto, há produtos que incluem a exploração dos arquivos manuscritos pessoanos. Esses foram utilizados como fontes de pesquisa, principalmente quando registravam exposições na CFP ou atividades relacionadas com a casa-museu.

O quarto andar da CFP é ocupado pelos funcionários ligados à gestão. Junto aos gabinetes de trabalho, estão os documentos administrativos, dentre os quais se destacam os dossiês de projetos, os programas, as fotografias e os dossiês de eventos. Essa documentação constitui a principal base empírica dos resultados obtidos nesta pesquisa.

A análise dos produtos, dos ambientes da CFP e da documentação administrativa permitiu identificar um total de 225 representações de arquivos manuscritos pessoanos. A distribuição quantitativa por ano pode ser verificada no Gráfico 1. 
Gráfico 1 - Série temporal das representações dos arquivos manuscritos presentes nas práticas, ambientes e produtos da Casa Fernando Pessoa em números absolutos por ano (1995-2017)

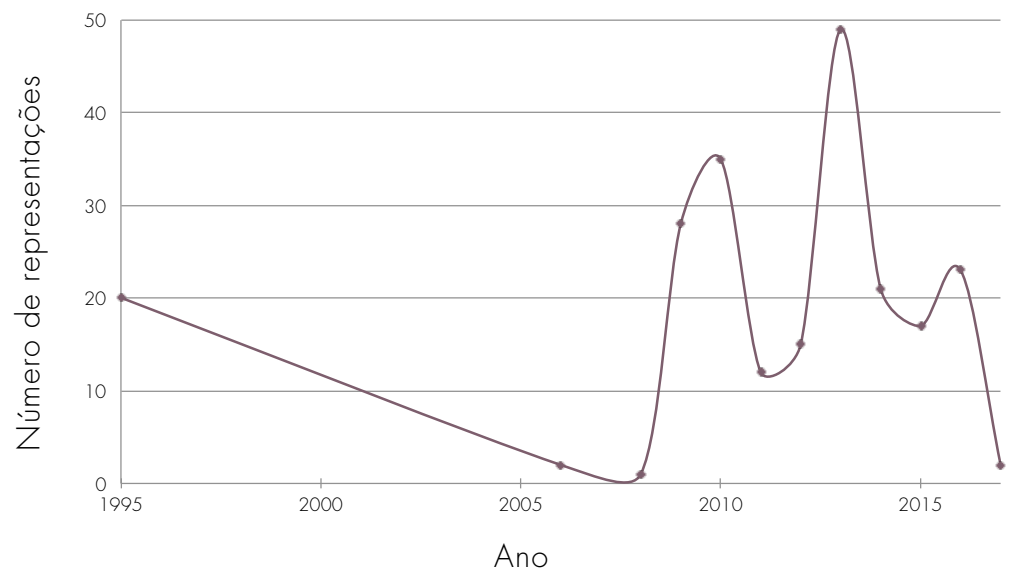

Fonte: Elaborado pelo autor com base em comunicados, dossiês de projetos, catálogos de exposições, folders, programas, planos de ação, fotografias, relatórios, livros, webpage institucional e observação direta dos ambientes da Casa Fernando Pessoa.

Todas estas representações foram mediadas no contexto das práticas relacionadas com o programa cultural da Casa Fernando Pessoa. As mediações ocorreram em práticas programadas. Identificou-se o total de 22 práticas sistematizadas, dividas por tipo no Gráfico 2.

Gráfico 2 - Série tipológica de práticas com a presença de representações dos arquivos manuscritos em números absolutos (1995-2017)

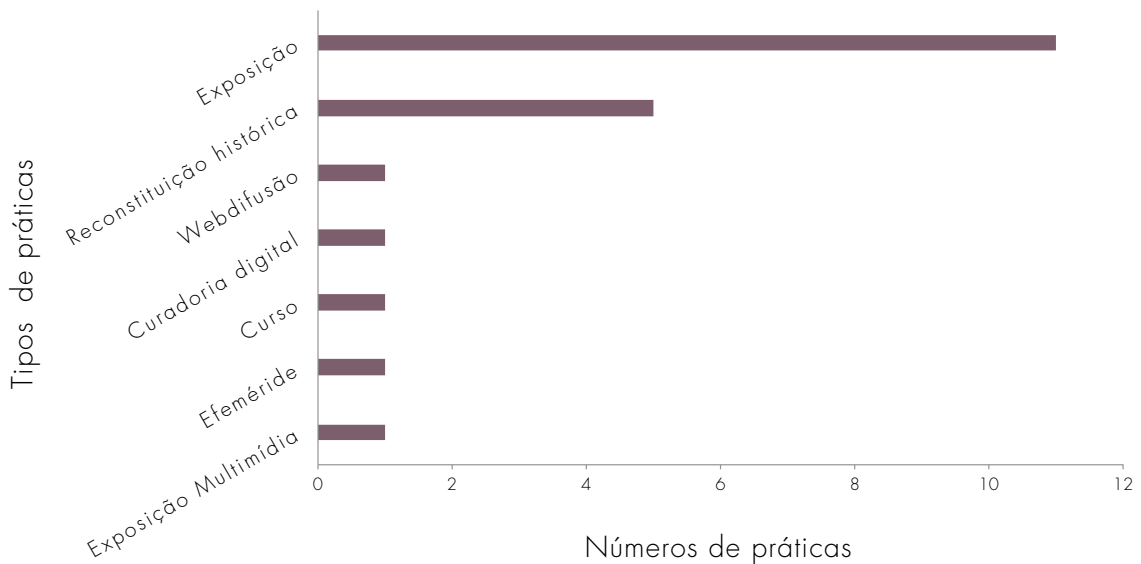

Fonte: Elaborado pelo autor com base em comunicados, dossiês de projetos, catálogos de exposições, folders, programas, planos de ação, fotografias, relatórios, livros, webpage institucional e observação direta dos ambientes da Casa Fernando Pessoa. 
Em se tratando das representações fac-similares, a materialidade é lastreada pela exploração dos valores afetivos dos arquivos manuscritos, isto é, não apenas pela imitação da anatomia da espécie ou tipo documental, mas principalmente pelo poder de provocar nos sujeitos a sensação de que o documento é real e histórico. Isso é possível pois as representações fac-similares fixam elementos extrínsecos ao suporte, que remetem à ideia do que seja um arquivo manuscrito histórico (por exemplo, a cor amarelada do papel, que confere um aspecto envelhecido à representação, a caligrafia, a assinatura e a datação). No quarto reconstituído de Pessoa há uma arca simulando o objeto usado para arquivar os escritos do poeta (Figura 1).

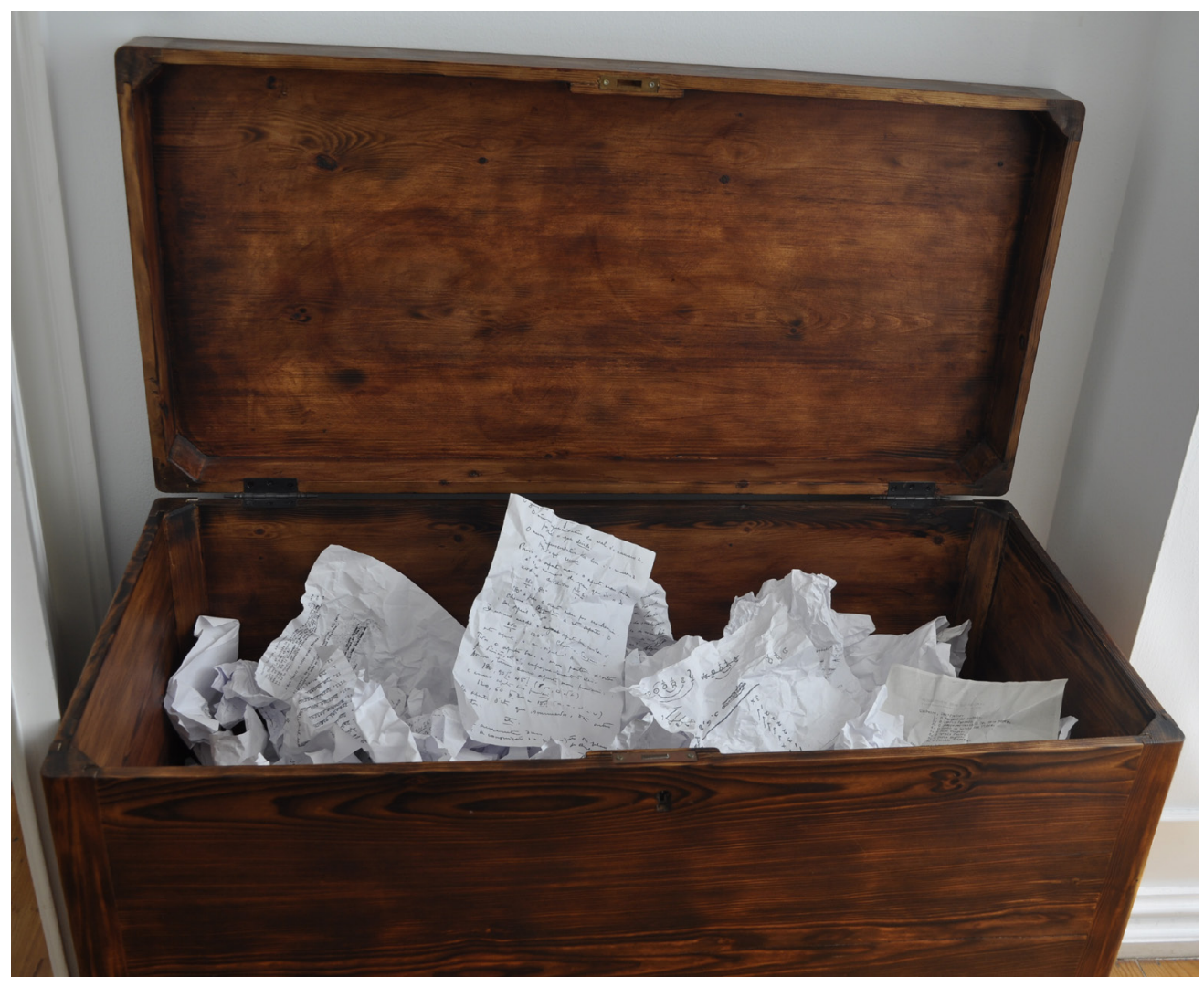

Figura 1 - Representações fac-similares na réplica da arca de Fernando Pessoa. Fonte: Acervo do autor (2016).

A reconstituição do quarto de Fernando Pessoa é o projeto mais antigo da casa-museu. A primeira reconstituição histórica do quarto de Pessoa ocorreu em 1994, tornando-se depois permanente e sofrendo modificações ao longo do tempo. A reconstituição dos quartos dos outros eus de Pessoa pode ser definida como uma exposição museal, uma montagem cenográfica e uma manifestação 
de uma museografia das ideias, tratando particularmente sobre como as ideias circulam e se materializam através de representações. Foram encontradas representações dos arquivos manuscritos nas seguintes reconstituições históricas: Quarto de Alberto Caieiro (2009), Quarto de Ricardo Reis (2010), Quarto de Bernardo Soares (20 1 1), Quarto "Ode Marítima" de Álvaro de Campos (2012) e Quarto de Raphael Baldaya (2013).

Na reconstituição dos quartos onde os outros eus de Pessoa coabitaram com o autor no plano das ideias é que a pluralidade da autoria pessoana pode ser manifestada mediante as referências literárias aos seus heterônimos, a partir das quais a casa-museu remonta espaços de exposição que dão um sentido de veracidade e/ou verossimilhança a esses autores fictícios. Nesse caso, as representações fac-similares resultam diretamente da exploração do valor formal e da configuração dos arquivos manuscritos de Pessoa, a fim de validar um espaço e conferir uma realidade que existe apenas no plano da literatura. Através da materialidade dessas representações é que o visitante pode sentir uma sensação de tangibilidade do universo literário. Um exemplo disso é a representação de um manuscrito datado de 26 de setembro de 1929 que é atribuído a Ofélia Queiroz (Figura 2). O teor do documento é uma resposta pungente de Ofélia para Álvaro de Campos afirmando que ela o jogaria debaixo de um trem. Se Campos fosse pessoa, então isso evidenciaria uma intenção homicida e/ou uma indireta ameaça de morte. Ocorre que Campos é o heterônimo homossexual de Pessoa e essa reação se deu por conta da correspondência enviada pelo autor em 25 de setembro de 1929 propondo que ela afogasse mentalmente a imagem de Pessoa. Além disso, nesta mensagem provocativa, Campos desautorizou Ofélia a diversas coisas tais como: comer pouco e pensar em Fernando Pessoa.

Estas representações não são tratadas apenas como meras reproduções de arquivos manuscritos, porque estão reforçando e validando um ambiente reconstituído como um lugar objetivamente histórico, quando na verdade são espaços ficcionalmente condicionados. Há ocorrências em que tais representações não se restringem a validar o espaço exposicional, vide que a carta supracitada revela intimidades sobre a vida amorosa de Pessoa tendo, portanto, também um efeito para emocionar o leitor que já conhece os trabalhos do literato. Atualmente o poder emotivo da documentação arquivística tem sido usado com fins comerciais, educativos, lúdicos, comemorativos, artísticos, de promoção institucional, regional ou nacional. ${ }^{114}$

No caso da CFP as ambiências dos quartos dos outros eus de Pessoa foram reconstituídas como se fossem personagens históricas que ali habitaram. As representações fac-similares foram alocadas neste reconstituir como se fossem 


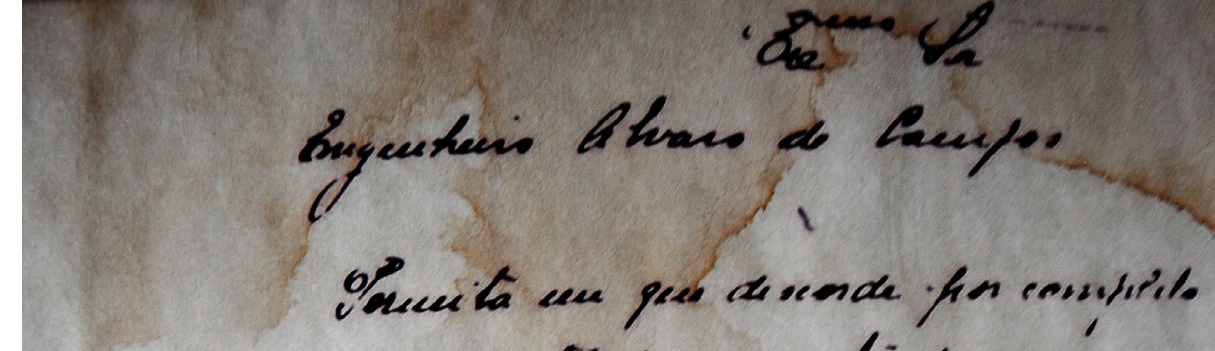

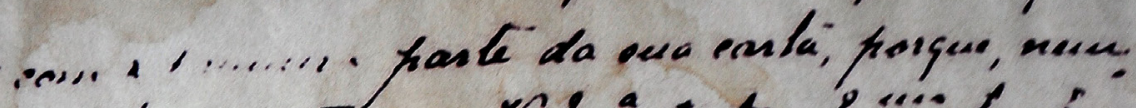

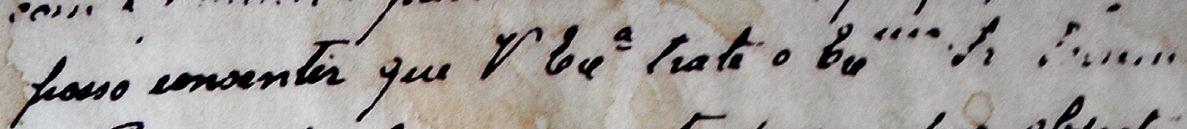

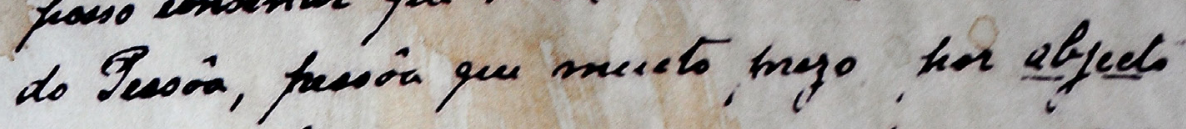

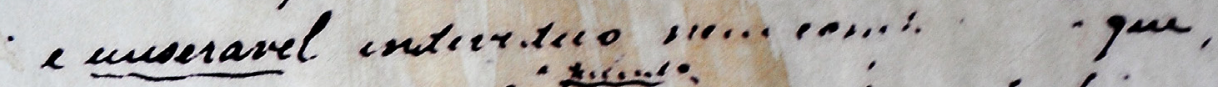

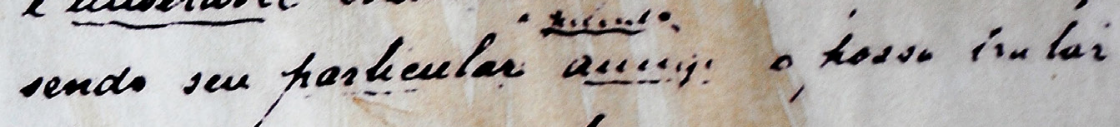

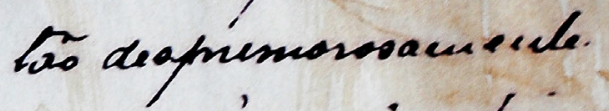

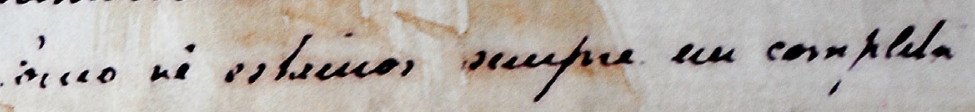

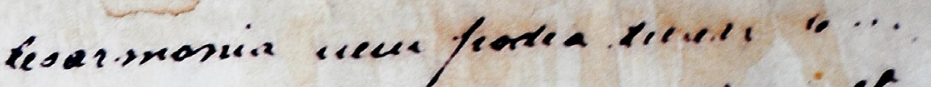

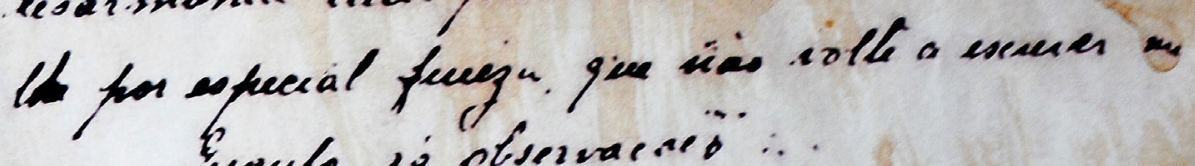

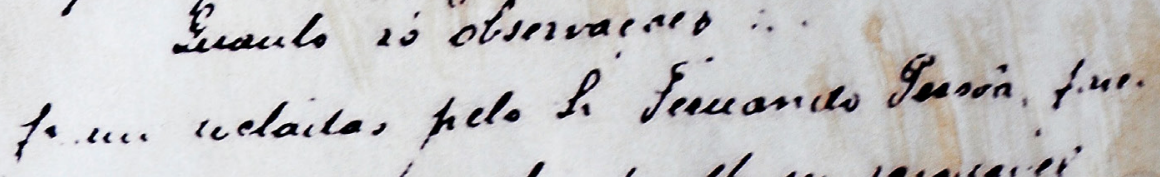

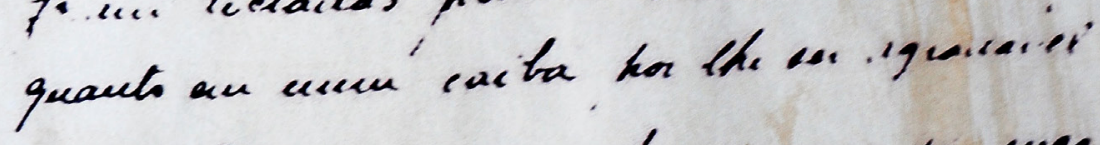

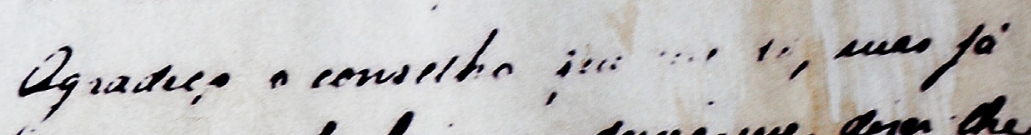

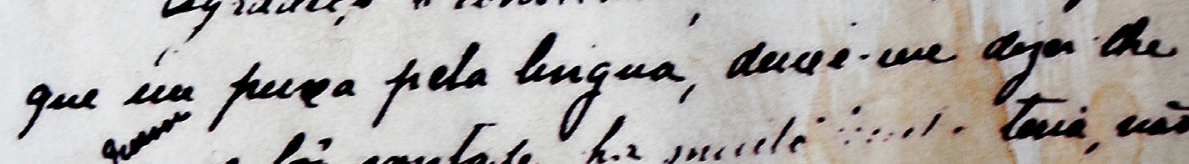

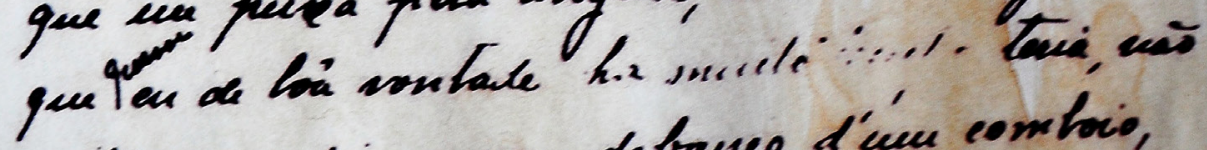
dectad na fie cuas detauso d'icue combio,

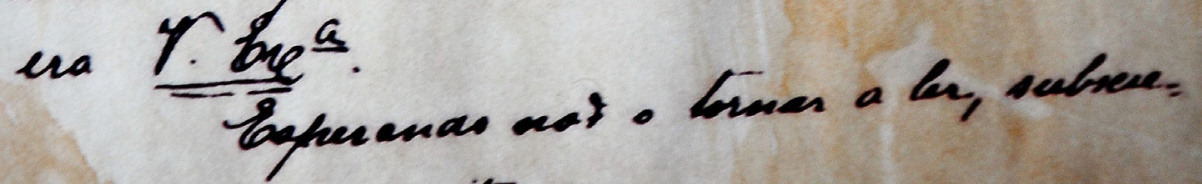
verse cosn reppeits a $269: 29$

Figura 2 - Representação da carta de Ofélia Queiroz para Álvaro de Campos tratando sobre Fernando Pessoa. Fonte: Acervo do autor (2017). 
115. Cf. Merleau-Ponty (1993).

116. Rodrigues; Marques (2005, p. 4). verdadeiras próteses ou extensões objetivas a fim de conferir materialidade a pessoas que existiram na vida intelectual de um autor cujo domínio literário é o conjunto da obra pessoana.

O contexto museal lastreado numa realidade ficcional é singular, pois não se tem conhecimento de outra casa-museu operando dentro de um discurso legitimador da realidade histórica, onde o público sabe de antemão que os artefatos ali expostos são produzidos a partir da literatura, de modo que é possível desfrutar da sensação de que a ficção pode se aproximar da realidade, porque está mais tangível, e o material se encontra em conformidade com o tempo, o lugar e as circunstancias de onde emergiu.

As representações fac-similares são, em resumo, simulacros de arquivos manuscritos recontextualizados em ambiências museais criadas através de reconstituições históricas que representam o discurso ficcional sobre e dos outros eus de Pessoa. Os heterônimos pessoanos, que somam um total de 136 autores fictícios, desempenham um papel em conjunto na obra de Pessoa, e foram criados para contradizê-lo e exorcizar medos, ansiedades e incertezas.

Já num outro campo de significação estão as representações artísticas que podem revelar a perspectiva do artista sobre os arquivos manuscritos, pois os documentos são representados a partir de uma lógica artística interpretativa e particular, decorrente da exploração dos valores formais/estéticos dos documentos. As representações artísticas remetem a uma ontologia do visível, pois se estabelecem como um tipo de registro decorrente do processo de tornar algo visível. ${ }^{115}$

É nesse encadeamento que os arquivos manuscritos são feitos visíveis através da representação artística, sendo o objeto mediado numa exposição que é "uma das mediações privilegiadas entre um conjunto de documentos (museográficos, arquivísticos ou bibliográficos) e que supõe certos recortes e certas escolhas, cujos objetivos principais podem ser o de inspirar, surpreender e educar". ${ }^{116}$

No caso da CFP, as exposições de arte destacam-se como uma forma de complemento à poesia, no contexto em que, dentre as atribuições institucionais, está o estímulo à poesia. Foram encontradas representações dos arquivos manuscritos de Pessoa nas seguintes exposições: "Um quarto de página" (1995), "Os lugares de Pessoa" (2008 - vigente), "A casa-poema" (2009 - vigente), "Agrimensor de metáforas" (2009), "A devolução da alma" (2009), "Pessoa, o bairro e o barro" (2012), "O mistério das cousas/Desassossego" (2012), "Pessoa-Astrólogo" (2013), "Poemas manuscritos" (2013), "Autopsicografia desassossego da imagem e da palavra: Pessoa/Voves" (2013) e "Nós, os de Orpheu" (2015 - vigente). 
Os arquivos de Pessoa(s) foram trazidos ao visível, assim como outros objetos retratados no processo artístico. As representações assumiram aspectos variados, como a presença das letras em formas cursivas como um sinal da caligrafia, a assinatura ou a marca de Pessoa, e isso ocorre principalmente nas pinturas e desenhos. Dentre as artes plásticas destacou-se a caracterização do tipo documental "cartas de amor". ${ }^{17}$ A exploração estética/formal das cartas de amor de Fernando Pessoa para Ophélia Queiroz (1902-1991) revela o potencial criativo e o valor emotivo dos documentos. Diferentemente das representações fac-similares, as artísticas enfocam aquilo que pode ser aprazível de contemplar, vide as três esculturas em argila coloridas de Tereza Cortez com dimensões de $9 \mathrm{~cm} \times 12 \mathrm{~cm} \times 13 \mathrm{~cm}$.

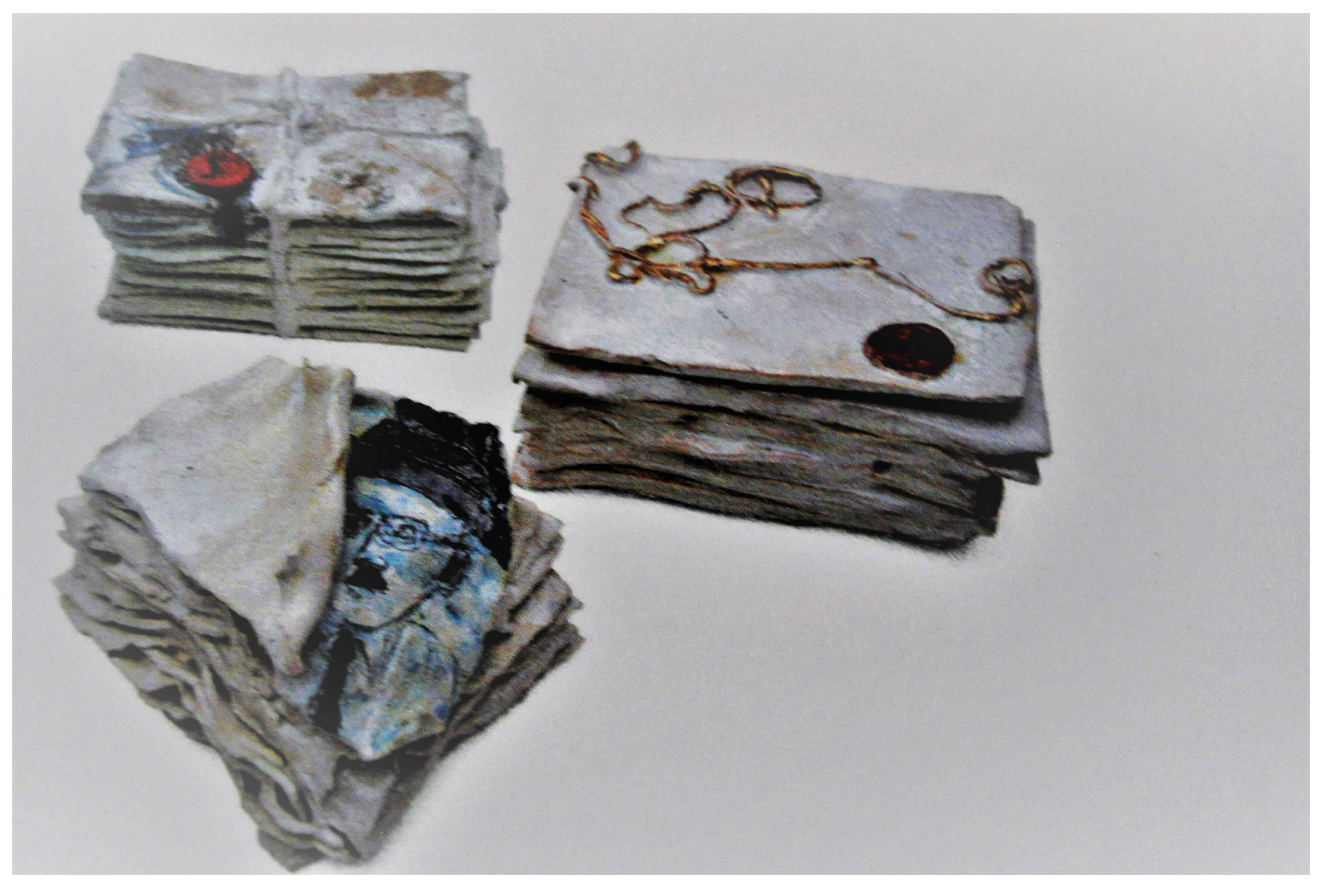

Figura 3 - Representações artísticas: cartas de amor de Pessoa para Ofélia por Tereza Cortez. Fonte: Reproduzido de Casa Fernando Pessoa (2011).

Tendo como foco principal a exploração do valor cognitivo para a fruição intelectual, as representações gráficas reproduzem os arquivos manuscritos no espaço do material impresso a partir de uma produção editorial que inclui as artes gráficas materializadas nos livros. As representações foram identificadas principalmente como imagens gráficas dos arquivos manuscritos de Pessoa, cuja extensão é, em geral, demarcada pela reprodução integral ou parcial dos documentos de arquivo. 
Em que pesem os produtos editoriais da CFP, foram encontradas representações gráficas que exploram os arquivos manuscritos, com destaque para a colaboração entre a CFP e a editora Boca no livro/CD bilíngue Nós, os de Orpheu/We, the Orpheu lot publicado em 2015.

Apesar de não serem considerados para o resultado quantitativo, porque sua produção não é decorrente das atividades da CFP, há produtos culturais ofertados na loja institucional. Dentre esses produtos distinguem-se pela exploração dos arquivos manuscritos as publicações da Tinta da China, do Grupo Leya, da Parceria A. M. Pereira, da Verso Kapa, da Porto Editora e da Texto Editora.

Também estão incluídos na cadeia produtiva da economia da cultura os seguintes parceiros da CFP na indústria editorial: Boca, Assírio \& Alvim, Publicações Dom Quixote, Contexto, P.E.N. Clube Português, Presença, Quetzal, Empresa de Gestão de Equipamentos e Animação Cultural, Imprensa Municipal de Lisboa, Câmara Municipal de Lisboa, Teorema, Alfragude, Salamandra, Centro de Linguística da Universidade de Lisboa, Cacém, Texto Editora, Fréon (Bruxelas), Só Volume, Departamento de Cultura, Instituto Português do Livro e das Bibliotecas e Pelouro da Cultura.

É como uma exterioridade que busca impactar a percepção visual que as representações visuais são aqui entendidas. Tendo em vista o espaço da CFP, as representações visuais dos arquivos manuscritos foram centradas em uma exposição multimídia denominada "Sonhatório/Dreamatorium" (2013 - vigente). Nesse caso o uso de recursos tecnológicos de armazenamento, processamento e projeção de imagens visuais é imprescindível para a recepção destas representações. Neste contexto a proposta caminha para o entretenimento educativo e para a experimentação da impressão visual dos manuscritos. É possível observar as representações projetadas sincronicamente sob um aspecto luminoso que ao final forma uma composição. Essa composição é gradual e disparada a partir do reconhecimento automático da entrada do visitante na câmara do "Sonhatório/Dreamatorium" (Figura 4), quando então há projeções contínuas de manuscritos/autógrafos de Pessoa que se sobrepõem luminosamente a partir do projetor de imagens.

Estabelecidas a partir da exploração de seu valor pragmático, as representações digitais são cópias que substituem os documentos apenas na sua leitura superficial, porque eles não mantêm vínculos autênticos com o original, não possuem a materialidade do arquivo manuscrito e são facilmente manipuláveis. Até certo ponto, as representações digitais emulam os documentos e podem ser compreendidas como um formato digital da documentação capturada por meios tecnológicos que podem ser tratados por meio de metadados. 


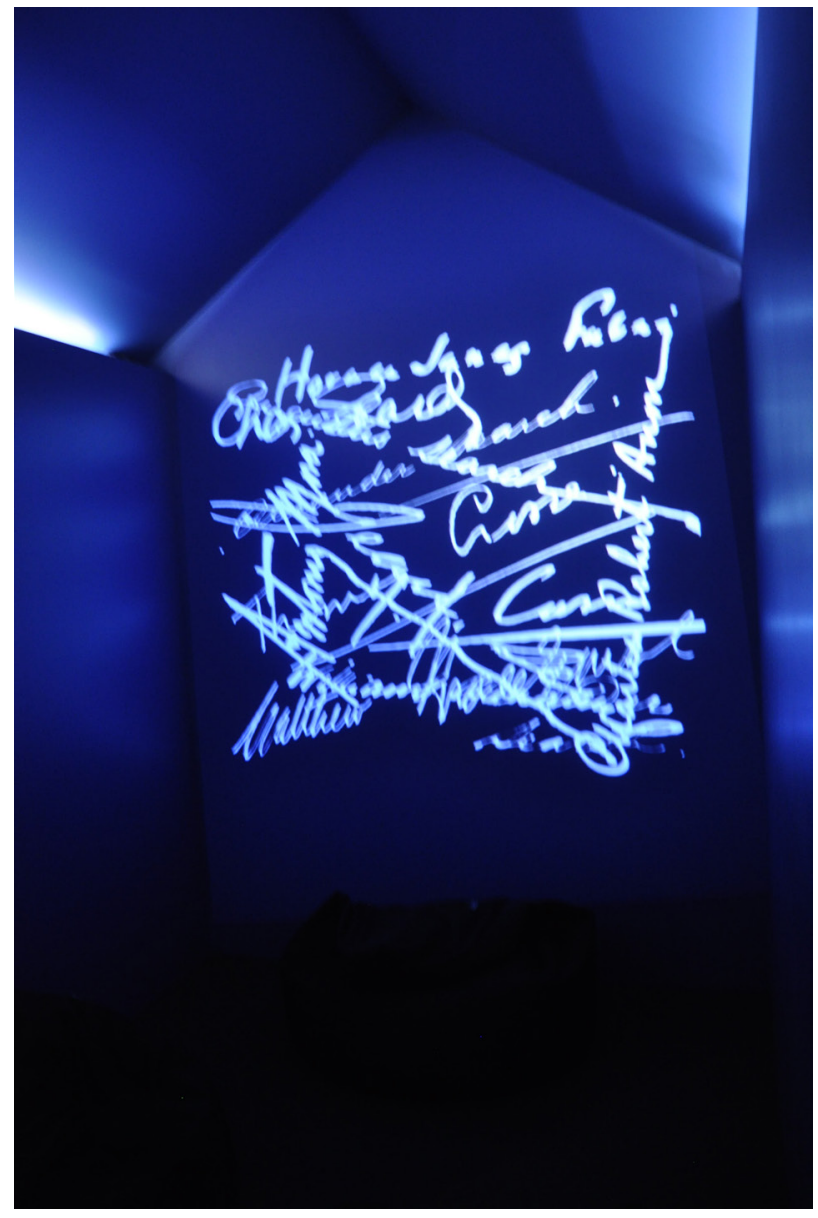

Figura 4 - Câmara do Sonhatório/ Dreamatorium. 2013. Fonte: Acervo do autor (2016).

As representações digitais do original estão associadas aos conteúdos resultantes da cópia e as questões essenciais de preservação desses conteúdos dizem respeito às ferramentas e às configurações tecnológicas. ${ }^{118}$ Nesse sentido a Biblioteca Digital da Casa Fernando Pessoa (BDCFP), lançada em 2010, vem tornando os conteúdos acessíveis. Ocorre que a BDCFP desempenha o papel de uma sala de leitura em um site institucional e mantém um padrão emissivo de transmissão. Essa ênfase na emissão pode levar a um descuido com a interatividade. Além disso, considerando a curadoria digital, é preciso observar os requisitos mínimos, como a preservação da autenticidade dos documentos. Cabe ressaltar que a CFP pode ter em conta que a BDCFP poderia vir a somar projetos como o Arquivo Digital Colaborativo do Livro do Desassossego da Universidade de Coimbra, no sentido de cooperar com uma iniciativa de descrição auxiliar a fim de reconstruir os vínculos entre as partes do fundo fechado de Pessoa sob custódia distribuída. 
Dados os milhões de internautas na web, as representações digitais são aquelas com o maior potencial para atingir um grande número de pessoas. Nessa direção as representações digitais também foram verificadas no perfil institucional da CFP nas redes sociais e, nesse caso, a sua exploração culmina num marketing via web das atividades da instituição. Dentro do contexto das redes sociais a representação digital é uma representação de outra representação, porque ela é utilizada como uma imagem para atrair a atenção dos internautas interessados em uma atividade relacionada com práticas que muitas vezes remetem, por exemplo, às representações artísticas. Assim o espaço da internet pode tornar as práticas culturais visíveis no ambiente digital, e o público das redes sociais (ou internautas) pode vir a ser o público das atividades culturais e educativas.

Dentre os tipos de práticas desenvolvidas na CFP, ressalta-se que tem predominado as exposições, e isso é natural, porque o espaço de uma casamuseu como a CFP é, essencialmente, aquele onde os visitantes têm a expectativa de ver algo. $\bigcirc$ serviço educativo exerceu um papel relevante em exposições e outras atividades, e os serviços da biblioteca da CFP convergiram com o serviço educativo, harmonizando o desfrute do valor formal/estético, emotivo e cognitivo. Nesse sentido destacaram-se os cursos, neste caso, o curso "Introdução à Astrologia de Fernando Pessoa" (2012-2013), pois no âmbito da prática ocorreu a exploração do valor cognitivo dos arquivos manuscritos com ênfase nas notas, cálculos e mapas astrológicos de Pessoa, que não deixaram de ser um deleite estético possível ao público.

A prática "Espólio(s) Pessoa" (2016) não foi numericamente e qualitativamente considerada, pois não foi possível medir a quantidade de representações utilizadas. No entanto, esta prática é uma das mais relevantes para a CFP no contexto da mediação cultural, pois permitiu a exploração de inéditos pessoanos. Isso significou que a CFP exerceu a democratização cultural no seu papel de mediadora, o que pode ser avaliado como substancial para a casamuseu, pois a própria mediação cultural é atividade fundamental aos museus, e isso não exclui as casas-museus, principalmente aquelas mais próximas dos públicos na esfera da municipalidade.

Em se tratando de práticas de mediação cultural com representação dos arquivos manuscritos, nota-se que houve valorização e exploração do material arquivístico. A valorização significou, objetivamente, a mediação no contexto de práticas educativas e culturais para fruição dos valores cognitivos, estéticos/formais e emotivos. A exploração decorreu da pluralização do uso dos arquivos de Pessoa(s) inclusive para fins comerciais das editoras e para empreendimentos culturais, artísticos e institucionais tanto da CFP quanto de suas parcerias. No caso 
da CFP é possível afirmar que a exploração está mais concentrada em práticas que resultam em produtos da indústria editorial.

Por fim é preciso recordar que a CFP é um lugar de convergência de materiais de arquivo, de biblioteca e de museu que mantém um vínculo com o setor privado, particularmente com as indústrias culturais e criativas, e em especial com o setor editorial, que esteve presente em catálogos produzidos para registrar as exposições e também em coletâneas de poesia, congressos, eventos e livros sobre Fernando Pessoa.

\section{CONSIDERAÇÕES FINAIS}

Conclui-se que o entendimento de espólio tem sido aplicado como forma de encobertar os artefatos materiais que realmente são tratados pela CFP: os arquivos de Pessoa(s). Os desdobramentos deste entendimento que alocou os arquivos na categoria de espólio são: a condescendência com a dispersão do acervo; o acomodamento com o colecionismo; a fragmentação do acervo; as mesclas com arquivos de proveniências distintas resultantes de adições indevidas ao conjunto documental; um descontrole sobre a preservação da autenticidade dos arquivos; a falta de representações arquivísticas e de vínculos funcionais entre os registros; a descontextualização das peças documentais; a atomização no domínio das Letras; a tematização do arquivo em detrimento da descrição arquivística; a desarticulação entre coleções particulares e públicas; a destituição de padrões de organização metodológica compatíveis com um fundo fechado de arquivo; e por fim, uma difusão incongruente com o sentido original dos arquivos de Pessoa(s).

Localiza-se a Casa Fernando Pessoa como lugar de convergência entre materiais de museus, arquivos e bibliotecas, ao mesmo tempo em que ali não se restabeleceram as interligações orgânicas entre a parte do acervo depositada na casa-museu com as demais partes, dispersas em instituições de custódia e coleções privadas.

A adoção do termo "espólio" impactou o tratamento documental pela própria ausência de representações arquivísticas. Essas, por sua vez, podem ser consideradas como as matrizes das demais. Isso empobreceu as atividades da CFP, de modo que a compreensão limitada da constituição do acervo da casamuseu reduz o benefício das práticas de mediação cultural, pois deixou de se fazer conhecer os arquivos totais de Pessoa como as fontes primárias daquilo que 
se medeia no espaço da casa-museu. A CFP perdeu a oportunidade de introduzir os cidadãos no universo arquivístico do qual dependem para fazer valer seus direitos, cumprir suas obrigações, afirmar suas identidades e reforçar os sentimentos de pertença a uma coletividade. Soma-se a isso o fato de que, se houvesse uma descrição ou representação arquivística dos documentos que levasse em conta o valor estético e emotivo dos arquivos, isso poderia potencializar a exploração destes valores nas representações dos manuscritos nas práticas de mediação cultural.

Constata-se, porém, que a CFP, mesmo sem práxis arquivística, tem contribuído, pelo menos em certa medida, para a democratização do patrimônio documental através de práticas de difusão e mediação cultural com arquivos manuscritos. Identificou-se a ocorrência de 22 dessas práticas classificadas nos seguintes tipos: recriações históricas, exposições, exposição multimídia, cursos, efemérides, webdifusão e curadoria digital. No que corresponde as categorias de representação presentes nas referidas práticas foram observadas as seguintes: representações gráficas, digitais, visuais, fac-similares e artísticas. $\bigcirc$ resultado quantitativo total dessas representações corresponde ao número de 225.

No plano das possibilidades, os resultados aqui expostos podem servir como quadro referencial para possíveis comparações, iniciativas, análises, avaliações, planejamentos e decisões no sentido do aperfeiçoamento das práticas institucionais com o material de arquivo. Pressupõe-se que, pelo menos, as seguintes instituições podem ter interesse na mediação cultural com arquivos: as casas-museu; os empreendimentos de editoração e digitalização; os centros de memória; as bibliotecas; os centros de investigação; os aparelhos culturais; os centros de documentação; os museus; os empreendimentos culturais; as empresas de tecnologia da informação e da comunicação; os órgãos públicos ligados ao patrimônio; os centros culturais; as universidades; os coletivos de artistas; as câmaras municipais; as cooperativas e as associações de profissionais da informação, de historiadores, de antropólogos, de cientistas sociais, de arquivistas, de bibliotecários e de museólogos. 


\section{REFERÊNCIAS}

ALBERCH I FUGUERAS, Ramon et al. Archivos y cultura: manual de dinamización. Gijón: Trea, 2001.

ALDABALDE, Taiguara Villela. Mediação cultural em instituições arquivísticas: o caso do Arquivo Público do Estado do Espírito Santo. 2015. 221 f., il. Tese (doutorado em Ciência da Informação) - Universidade de Brasília, Brasília, 2015.

ARQUIVO NACIONAL (Brasil). Dicionário brasileiro de terminologia arquivística. Rio de Janeiro: Arquivo Nacional, 2005. (Publicações Técnicas, 51).

ASSOCIATION OF INDEPENDENT MUSEUMS et al. A code of practice on archives for museums and galleries in the United Kingdom. London, 2002. Disponível em: <https://bit.ly/2DOJtHh>. Acesso em: 7 jun. 2018.

AYERS, Susan, et. al. Cambridge handbook of psychology, health and medicine. 2. ed. Cambridge: Cambridge University Press, 2007.

BASTOS, Aurélio Wander, ARAÚJO, Rosalina Corrêa. A legislação e a política de arquivo no Brasil. Acervo, Rio de Janeiro, v. 4-5, n. 1-2, p. 19-33, jul. 1989.

BELLOFIORE, Riccardo; CARTER, Scott. Towards a new understanding of Sraffa: insights from archival research. Basingstoke: Palgrave Macmillan, 2014.

BELLOTTO, Heloisa Liberalli. Arquivos permanentes: tratamento documental. 4. ed. Rio de Janeiro: Editora FGV, 2002.

Arquivos pessoais em face da teoria arquivística tradicional: debate com Terry Cook. Estudos Históricos, São Paulo, v. 11, n. 21, p. 201-207, 1998.

BETHÂNIA, Maria. Dentro do mar tem rio. Rio de Janeiro: Biscoito Fino, c2008. 2 CDs.

BIBLIOTECA NACIONAL DE PORTUGAL. Espólio de Fernando Pessoa: inventário. Lisboa: Biblioteca Nacional, 1986. 
BLANCO, José. Pessoana. Lisboa: Assírio \& Alvim: 2008. 2 v.

BLOOM, Harold. El canon occidental: la escuela y los libros de todas las épocas. Barcelona: Anagrama, 2005.

BOLOFER, Juan. "La Real Falúa": una escena del veraneo de la Corte en el archivo manuscrito de El Ruedo Ibérico de Ramón del Valle-Inclán. Bulletin of Hispanic Studies, Liverpool, v. 92, n. 7, p. 791-804, 2015.

BREM, Walter. Archival manuscript collections on microfilm wibout online catalog records: overview of microfilm binders 4-38. Berkeley: University of California, 2006.

CAMARgO, Ana Maria de Almeida. Arquivos pessoais são arquivos. Revista do Arquivo Público Mineiro, Belo Horizonte, v. 45, n. 2, p. 27-39, 2009.

À guisa de apresentação. In: OLIVEIRA, Lucia Maria Velloso de. Descrição e pesquisa: reflexões em torno dos arquivos pessoais. Rio de Janeiro: Móbile, 2012. p. 7-12.

CARVAlHO, José. Campo de Ourique: a aldeia de Lisboa. Lisboa: Quimera, 2014.

CASA FERNANDO PESSOA. Nós, os de Orpheu/We, the Orpheu lot. Lisboa: Boca, 2015.

Pessoa, o bairro e o barro: cerâmica e desenho de Tereza Cortez: uma exposição na Casa Fernando Pessoa. Lisboa: Imprensa Municipal de Lisboa, 2011.

CAVAlCANTI FILHO, José Paulo. Fernando Pessoa: uma quase-autobiografia. Porto: Porto, 2012.

CAVAlHEIRO, Marcos; RODRIGUEZ, Sonia. Arquivo e literatura: perspectivas de acesso e difusão da memória literária no Brasil. Archeion Online, João Pessoa, v.1, n .1, p. 45-52, 2013. Disponível em: <https://bit.ly/2HZCo90>. Acesso em: 7 jun. 2018.

CHARTIER, Roger. Defense et illustration de la notion de représentation. Working Papers des Sonderforschungsbereiches, Berlin, v. 640, n. 2, p. 3-12, 2011. Disponível em: <https://bit. ly/2FWrvZ4>. Acesso em: 7 jun. 2018.

A história cultural entre práticas e representações. Lisboa: Difel, 2002. (Coleção Memória e Sociedade). 
COOK, Terry. An archival revolution: W. Kaye Lamb and the transformation of the archival profession. Archivaria, Ottawa, n. 60, p.185-234, 2005.

. Obituary: Bruce Gordon Wilson, 1946-1998. Archivaria, Ottawa, n. 44, p.188-191, 1997.

COUTURE, Carol et al. Les fonctions de l'archivistique contemporaine. Québec: Presses de l'Université du Québec, 1999.

DAL FARRA, Maria Lúcia. Os interpostos Pessoas na correspondência com Ophélia. Revista Conexão Letras. v. 10, n. 14. Porto Alegre: 2015. p.25-34

DIX, Steffen. Um encontro impossível e um suicídio possível: Fernando Pessoa e Aleister Crowley. In: PIZARRO, Jerónimo (Org.). Fernando Pessoa: o guardador de papéis. 2. ed. Lisboa: Texto, 2009. p. 39-81.

DUARTE, Luiz Fagundes. As mãos da escrita. In: LOPES, Fátima (Coord.). As mãos da escrita: 25 anos do Arquivo de Cultura Portuguesa Contemporânea. Lisboa: Biblioteca Nacional, 2007. p. 17-28.

DUFF, Wendy; HAWORTH, Kent. The reclamation of archival description: the Canadian perspective. Archivaria, Ottawa, n. 31, p. 26-35, 1990.

EMPRESA DE GESTÃO DE EQUIPAMENTOS DE ANIMAÇÃO CULTURAL. Instrumentos de gestão provisional 2015. Lisboa: Câmara de Lisboa, 2015. Disponível em: <https://bit. ly/2t6CeYF>. Acesso em: 13 ago. 2017.

ESPÓLIO de Fernando Pessoa pode ultrapassar os 400.000 euros. RTP Notícias, Lisboa, 8 nov. 2008. Disponível em: <https://bit.ly/2DPrb8R>. Acesso em: 7 jun. 2018.

FARGE, Arlette. O sabor do arquivo. São Paulo: Edusp, 2009.

FAULKHEAD, Shannon; THORPE, Kristen. Dedication: archives and indiginous communities. In: GILLILAND, Anne; MCKEMMISH, Sue; LAU, Andrew (Org.). Research in the archival multiverse. Clayton: Monash University Publishing, 2017. p. 2-15.

FRISCH, Scott. Doing archival research in political science. Amherst: Cambria Press, 2012.

GALHOZ, Maria Aliete. A fortuna editorial pessoana e seus problemas: o caso da poesia. In: PESSOA, Fernando. Mensagem: poemas esotéricos. Edição crítica de José Augusto Seabra. Madrid: Archivos, 1993. p. 216-226. 
GILLILAND, Anne. Archival and recordkeeping traditions in the multiverse and their importance for researching situations and situating research. In: GILLILAND, Anne; MCKEMMISH, Sue; LAU, Andrew. (Org.). Research in the archival multiverse. Clayton: Monash University Publishing, 2017. p. 31-73.

GILliLAND, Anne; MCKEMMISH, Sue; LAU, Andrew. Preface. In: (Org.). Research in the archival multiverse. Clayton: Monash University Publishing, 2017. p. 16-30.

GOMES, Luísa Costa. Pessoa por descobrir. Ler, Lisboa, p. 49, 2009.

GORYAEVA, Tatiana. Archives and cultural diplomacy: international archival-museum design. In: ICA INTERNATIONAL CONGRESS, 2016, Seoul. Abstracts and biographies. Paris: International Council on Archives, 2016.

GROUP FOR LITERARY ARCHIVES AND MANUSCRIPTS. What are literary archives?. University of Leeds, Leeds, 2011. Disponível em: <https://bit.ly/2IOLfLV>. Acesso em: 31 maio 2017.

HARVARD UNIVERSITY. Zotero for archival research. Harvard Library, Cambridge, 2017. Disponível em: <https://bit.ly/2JOqMeE>. Acesso em: 14 jun. 2018.

HIRAUX, Françoise. Les archives personnelles, miroir des valeurs et des attentes de l'Occident. Une histoire culturelle et archivistique. In: HIRAUX, Françoise; MIRGUET, Françoise. Les archives personnelles. Louvain: Academia-L'Harmattan, 2013. p. 9-30.

HUANG, Philip; BERNHARDT, Kathryn. Research from archival case records: law, society and culture in China. Leiden: Brill, 2014.

INSTITUTO DOS MUSEUS E DA CONSERVAÇÃO. Normas de inventário para espólio documental: artes plásticas e artes decorativas. Lisboa: Ministério da Cultura, 2008.

INSTITUTO PORTUGUÊS DA QUALIDADE. Norma portuguesa de informação e documentação: terminologia arquivística: conceitos básicos. Lisboa, 2005.

INTERNATIONAL COUNCIL ON ARCHIVES. Code of ethics. Paris: International Council on Archives, 1996. Disponível em <https://bit.ly/2pEUVQK>. Acesso em: 7 jun. 2018.

JAMMET, Yves. La médiation au servisse des publics: les enjeux, les moyes, les experiencies: 1'action educative et culturalle des archives. In: QUELLE POLITIQUE CULTURELLE POUR LES SERVICES ÉDUCATIFS DES ARCHIVES?, Paris, 2007. Actes... 
KENT, Allen. Encyclopedia of library and information science. Boca Raton: CRC, 2002. v. 71.

KURTZ, Michael. Managing archival manuscripts and repositories. Chicago: Society of American Archivists, 2004.

LEÃO, Isabel Ponce de; LIRA, Sérgio. Museu Agustina Bessa-Luís. In: SEMINÁRIO DE INVESTIGAÇÃO EM MUSEOLOGIA DOS PAÍSES DE LÍNGUA PORTUGUESA E ESPANHOLA, 1., Porto, 2010. Actas... Porto: Edições da Universidade do Porto, 2010.

LE CONTRAT de mariage de Napoléon et Joséphine s'envole à 440.000 euros. La Tribune, Paris, 22 set. 2014. Disponível em: <https://bit.ly/2ILmwbC>. Acesso em: 7 jun. 2018.

LES DOCUMENTS intimes de Marcel Proust dispersés pour 1,24 million d'euros aux enchères. 20 minutes, Paris, 1 jun. 2016. Disponível em: <https://bit.ly/2Giom59>. Acesso em: 7 jun. 2018.

LEMAY, Yvon. Comment valoriser? Les options possibles et leurs implications. In: HIRAUX, Françoise; MIRGUET, Françoise (Org). La valorisation des archives: une mission, des motivations, des modalités, des collaborations. Louvain: Academia-L’Harmattan, 2012. p. 65-85.

Préparer aujourd'hui les voix de l'avenir. In: SERVAIS, Paul; MIRGUET, Françoise (Coord.). Archivistes de 2030: réflexions prospectives. Louvain: Academia-L'Harmattan, 2015. p. 285-304.

LODOLINI, Elio. Archivistica: principi e problemi. 15. ed. Milano: Franco Angeli, 2013.

LOPES, Fátima. Como se trabalha no Arquivo de Cultura Portuguesa Contemporânea. In: (Coord.) As mãos da escrita: 25 anos do Arquivo de Cultura Portuguesa Contemporânea. Lisboa: Biblioteca Nacional, 2007. p. 51-74.

LOPES, Teresa Rita. Fernando Pessoa et le drame symboliste: héritage et création. 2. ed. Paris: Fundação Calouste Gulbenkian, 1985.

Orpheu em tempo de guerra(s). In: VILA MAIOR, Dionísio; RITA, Annabela (Org.). 100 Orpheu. Lisboa: Edições Esgotadas, 2016. p. 415-426.

Pessoa por conhecer: roteiro para uma expedição. Lisboa: Estampa, 1990.

LUBAR, Steven. Information culture and the archival record. The American Archivist, Chicago, v. 62 , p. 10-22, 1999. 
MAIRESSE, François. La médiation culturalle et la université. In: SERAIN, Fanny et al. $L a$ médiation culturalle: cinqueème rou du carrosse. Paris: L'Harmattan, 2016. (Collection Patrimoines \& Sociétés). p. 95-102.

MARTINS, Fernando. Dicionário de Fernando Pessoa e do modernismo português. Leya: São Paulo, 2010.

MCKEMMISH, Sue. Recordkeeping in the continuum: an Australian tradition. In: GILLILAND, Anne; MCKEMMISH, Sue; LAU, Andrew (Org.). Research in the archival multiverse. Clayton: Monash University Publishing, 2017. p. 122-160.

MCLAUGHLIN, Mark. Archive buys up Dundas 'jewels' history. The Press and Journal, Inverness, 4 jul. 2012. Disponível em: <https://bit.ly/2pwObFi>. Acesso em: 7 jun. 2018.

MEIRELES, Maurício. Caixa com inéditos de Fernando Pessoa é encontrada na África do Sul. Folha de São Paulo, São Paulo, 16 jan. 2016. Disponível em: <https://bit.ly/1nptwiF>. Acesso em: 7 jun. 2018.

MENESES, Ulpiano. O campo do patrimônio cultural: uma revisão de premissas. In: FÓRUM NACIONAL DE PATRIMÔNIO CULTURAL, 1., Brasília, DF, 2010. Anais.... Brasília: Iphan, 2010. Disponível em: <https://bit.ly/2pAsqTX>. Acesso em: 9 dez. 2015.

MERLEAU-PONTY, Claire. Vous avez dit médiation? Les Cahiers de l'École du Louvre, n. 7, Paris, p. 86-88, 2015. Disponível em: <http://cel.revues.org/293>. Acesso em: 7 jun. 2018.

MERLEAU-PONTY, Maurice. Eye and mind. In: JOHNSON, Galen (Ed.). The MerleauPonty aesthetics reader: philosophy and painting. Evanston: Northwestern University Press, 1993. p. 121-149.

MOORE, Niamh, et. al. The Archive Project: archival research in the social sciences. Londres: Routledge, 2016.

MOTA, Pedro. O testamento da arca: o templo. In: Um século de Pessoa: encontro internacional do centenário de Fernando Pessoa. Lisboa: Fundação Calouste Gulbenkian, 1990. p. 239-244.

OLIVEIRA, Antonio Braz de. Arquivística literária: notas de memória e perspectiva. Veredas, Porto Alegre, n. 8, p. 373-382, 2007. 
OLIVEIRA, Lucia Maria Velloso de. Descrição e pesquisa: reflexões em torno dos arquivos pessoais. Rio de Janeiro: Móbile, 2012.

OWENS, Brian. The archival manuscript and the book: tools of knowledge and artifacts of destruction during the Napoleonic Wars and the War of 1812. Library E Archival Security, Pennsylvania, v. 25, n. 1, p. 5-19. 2012.

PIZARRO, Jerónimo (Ed.). Documentos que não se encontram na BNP. In: PESSOA, Fernando. Livro do desassossego. Lisboa: Tinta da China, 2013. p. 521-531.

PIZARRO, Jerónimo; FERRARI, Patricio. Apresentação. In: PESSOA, Fernando. Eu sou uma antologia: 136 autores fictícios. Lisboa: Tinta da China, 2016.

PESSOA, Fernando. O arquivo de correspondência. Revista de Comércio e Contabilidade, Lisboa, n. 4, p. 121-125, 1926. Disponível em: <https://bit.ly/2G61i6y>. Acesso em: 23 nov. 2016.

PORTUGAL. Assembleia da República. Lei n. ${ }^{\circ}$ 13/85, de 6 de julho de 1985. Diário da República, Lisboa, 6 jul. 1985. Série I, n. 153, p. 271-303. Disponível em: <https://bit. ly/2IMZ5if>. Acesso em: 7 jun. 2018.

Ministério da Cultura. Diário da República, Lisboa, 14 set. 2009. Série I, n. 178, p. 6312-6313.

REKRUT, Ala. Material literacy: reading records as material culture. Archivaria, Ottawa, n. 60, p. 11-37, 2005.

RISO, Clara. Actividade e posicionamento da Casa Fernando Pessoa. Jornal Regional, Lisboa, n. 30, p. 9, 23 out. 2015.

RITA, Annabela. Mensagem em moldura epocal. In: VILA MAIOR, Dionísio; RITA, Annabela (Org.). 100 Orpheu. Lisboa: Edições Esgotadas, 2016. p. 415-426.

RODES, Jean-Michel; PIEJUT; Geneviève, PLAS, Emmanuelle. Memory of the information society. Paris: UNESCO, 2003.

RODRIGUES, Georgete Medleg. A representação da informação em arquivística: uma abordagem a partir da perspectiva da Norma Internacional de Descrição Arquivística. In: RODRIGUES, Georgete Medleg; LOPES, Ilza Leite (Org.). Organização e representação do conbecimento na perspectiva da ciência da informação. Brasília: CID; Thesaurus, 2003. p. 210-229. 
RODRIGUES, Georgete Medleg; MARQUES, Angelica Alves da Cunha. Rastros de memórias, história de uma geração: a exposição Renato Russo Manfredini Jr. Patrimônio e Memória, Assis, v. 1, n. 2, p. 1-14, 2005.

ROUSSEAU, Jean-Yves; COUTURE, Carol. Os fundamentos da disciplina arquivística. Lisboa: Dom Quixote, 1998.

ROYAL SCHOOL OF LIBRARY AND INFORMATION SCIENCE. Cultural mediation. Copenhagen: University of Copenhagen, 1999. Disponível em: <https://bit.ly/2tj2lLg >. Acesso em: 13 jun. 2018.

SÁ-CARNEIRO, Mário de. Em ouro e alma: correspondência com Fernando Pessoa. Organizado por Ricardo Vasconcelos e Jerónimo Pizarro. Lisboa: Tinta da China, 2015.

SEPÚlVEDA, Pedro. Pessoas-livros: o arquivo bibliográfico de Fernando Pessoa. Materialidades da Literatura, Lisboa, v. 2, n. 1, p. 55-77, 2014.

SHELLENBERG, Theodore. Arquivos modernos: princípios e técnicas. Rio de Janeiro: FGV, 2006.

SILVA, Luiz Antonio Santana da; MADIO, Telma Campanha de Carvalho. Uma discussão sobre documento audiovisual enquanto patrimônio arquivístico cultural no Brasil. Ibersid, v. 6, p. 179-185, 2012. Disponível em: <https://bit.ly/2I1c4eN>. Acesso em: 12 nov. 2016.

STICHELBAUT, Birger. Forgotten and lost?: archival research of aerial photographic collections of the western front 1914-1918. Ljubljana, 2015. Disponível em: <https://bit.ly/2t62a6E >. Acesso em: 15 jun. 2018.

TAYLOR, Hugh. Clio in the raw: archival manuscripts and the teaching of history. The American Archivist, Chicago, v. 35, p. 317-330, 1972.

VELA, Susanna. Tipología de actividades. In: ALBERCH I FUGUERAS, Ramon et al. Archivos y cultura: manual de dinamización. Gijón: Trea, 2001. p. 159-163.

VILA MAIOR, Dionísio. Do Ultimato ao Ultimatum: a vitalidade nacional. In: RITA, Annabela; VILA MAIOR, Dionísio (Coord.). Do Ultimato à(s) república(s): variações literárias e culturais. Lisboa: Esfera do Caos, 2011. p. 113-135.

VILA MAIOR, Dionísio. Fernando Pessoa: heteronímia e dialogismo: o contributo de Mikhaïl Bakhtine. Coimbra: Livraria Almedina, 1994. 
ZAS, Margarita; RODRÍGUEZ, Francisca; REY, Rosario. La creación y gestión del archivo digital valleinclaniano: corpus manuscrito e impreso. In: LÓPEZ POZA, Sagrario; SUEIRO, Nieves Pena (Ed.). Humanidades digitales: desafíos, logros y perspectivas de futuro. Coruña: Universidade da Coruña, 2014. p. 435-457.

Artigo apresentado em 04/02/2017. Aprovado em 01/08/2017.

All the contents of this journal, except where otherwise noted, is licensed under a Creative Commons Attribution License (cc) BY 